Nevada

Environmental

Restoration

Project

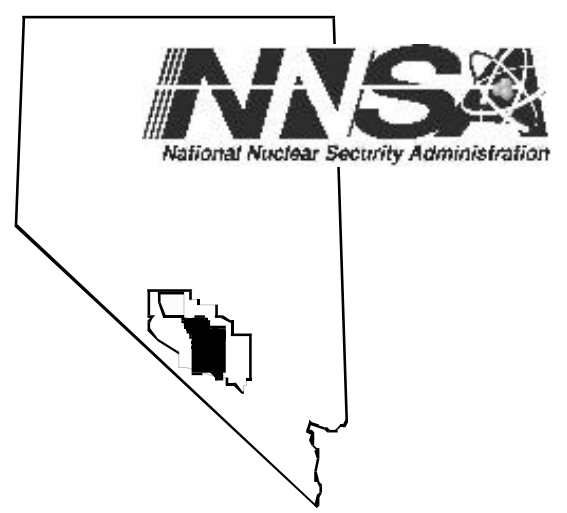

\title{
Completion Report for Well ER-EC-7
}

October 2004

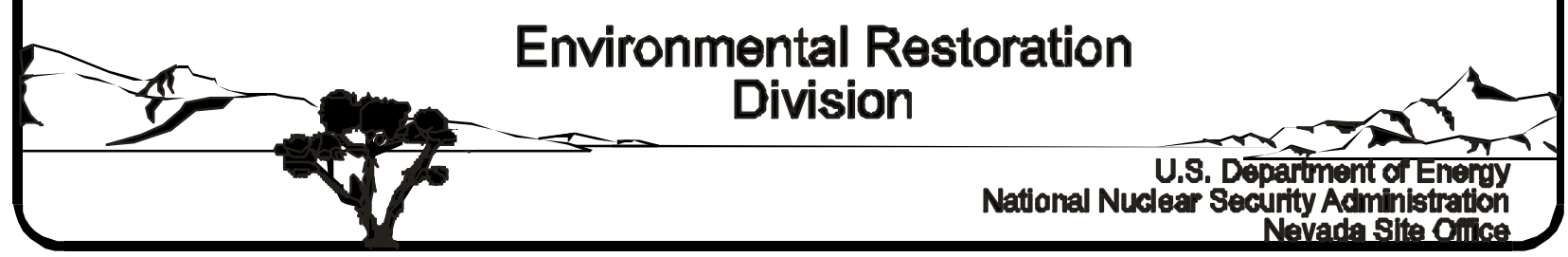




\title{
DISCLAIMER STATEMENT
}

Reference herein to any specific commercial product, process, or service by trade name, trademark, manufacturer, or otherwise, does not necessarily constitute or imply its endorsement, recommendation, or favoring by the U.S. Government or any agency thereof or its contractors or subcontractors.

\section{AVAILABILITY STATEMENT}

Available to the public, in paper, from:

\author{
U.S. Department of Commerce \\ National Technical Information Service \\ 5285 Port Royal Road \\ Springfield, VA, 22161-0002 \\ Telephone: 800.553 .6847 or 703.605 .6000 \\ Fax: 703.605.6900 \\ E-mail: orders@ntis.gov \\ Online ordering: http://www.ntis.gov/ordering.htm
}

Available electronically at http://www.osti.gov/bridge

Available for a processing fee to U.S. Department of Energy and its contractors, in paper, from:

U.S. Department of Energy

Office of Scientific and Technical Information

P.O. Box 62

Oak Ridge, TN, 37831-0062

Telephone: 865.576 .8401

Fax: 865.576.5728

E-mail: reports@adonis.osti.gov 


\title{
Completion Report for Well ER-EC-7
}

\author{
Prepared for: \\ U.S. Department of Energy \\ National Nuclear Security Administration \\ Nevada Site Office \\ Las Vegas, Nevada
}

Prepared by:

Bechtel Nevada

Geotechnical Sciences

Las Vegas, NV

October 2004 
This page intentionally left blank. 


\section{COMPLETION REPORT FOR WELL ER-EC-7}

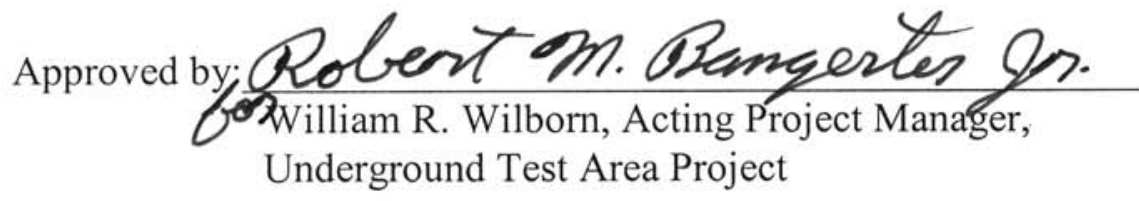

Date: $12 / 8 / 04$ Underground Test Area Project
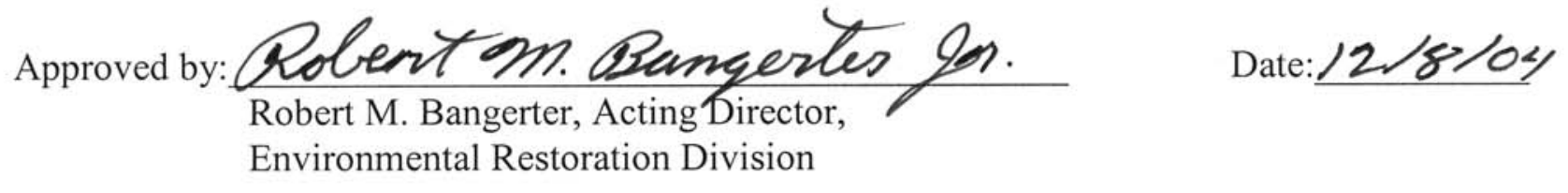

Environmental Restoration Division 
This page intentionally left blank. 


\title{
Completion Report for Well ER-EC-7 \\ DOE/NV/11718--467
}

\begin{abstract}
Well ER-EC-7 was drilled for the U.S. Department of Energy, National Nuclear Security Administration Nevada Site Office in support of the Nevada Environmental Restoration Project at the Nevada Test Site, Nye County, Nevada. This well was drilled in the summer of 1999 as part of the Department of Energy's hydrogeologic investigation program in the Western Pahute Mesa - Oasis Valley region just west of the Test Site. A 44.5-centimeter surface hole was drilled and cased off to a depth of 265.8 meters below the surface. The hole diameter was then decreased to 31.1 centimeters for drilling to a total depth of 422.5 meters. The planned depth of 762 meters was not reached due to borehole stability problems.
\end{abstract}

One completion string with two isolated slotted intervals was installed in the well. A preliminary composite, static, water level was measured at the depth of 227.8 meters, 20 days after installation of the completion string.

Detailed lithologic descriptions with stratigraphic assignments are included in the report. These are based on composite drill cuttings, supplemented by geophysical log data, and incorporating data from detailed chemical and mineralogical studies of rock samples. Beneath a thin alluvial deposit, the well penetrated 410 meters of lava and bedded tuff of the Volcanics of Fortymile Canyon Group, deposited in the Timber Mountain caldera moat after caldera collapse. The geologic interpretation of data from this well provides information on the thickness, lithologic composition, and hydrogeologic character of moat-filling rocks in the southern portion of the Timber Mountain caldera complex in the southwestern Nevada volcanic field. 
This page intentionally left blank. 


\section{Table of Contents}

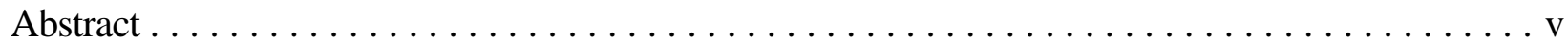

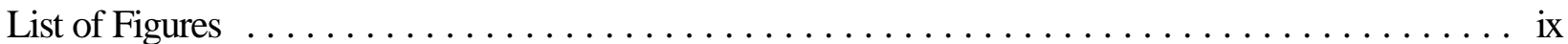

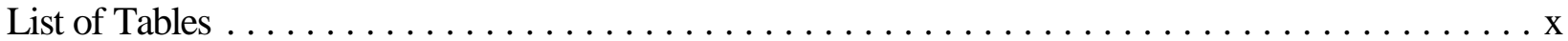

List of Acronyms and Abbreviations $\ldots \ldots \ldots \ldots \ldots \ldots \ldots \ldots \ldots \ldots \ldots \ldots \ldots \ldots \ldots \ldots$

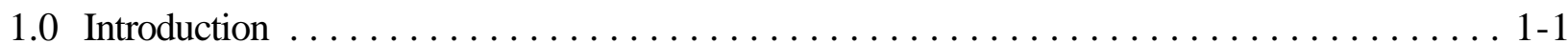

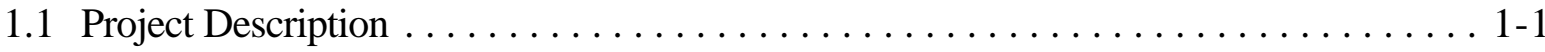

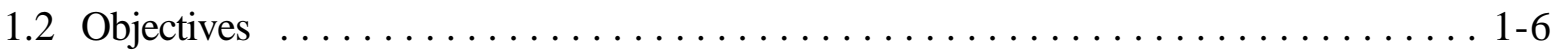

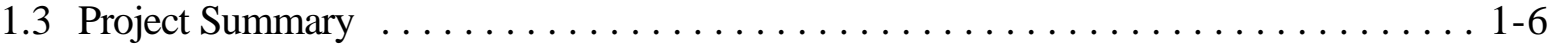

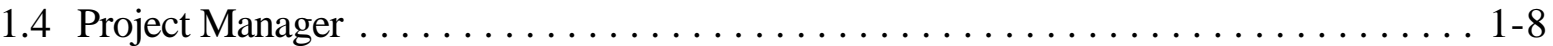

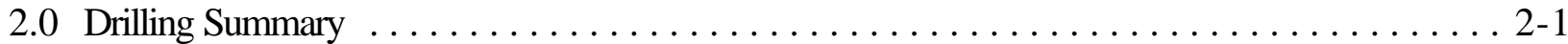

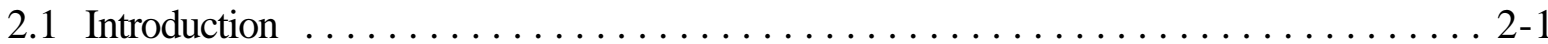

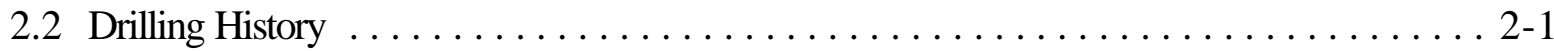

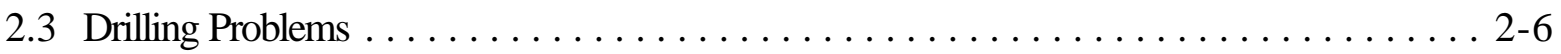

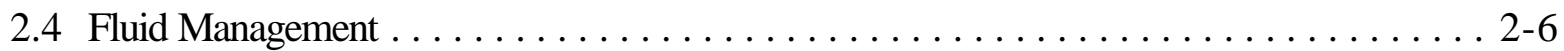

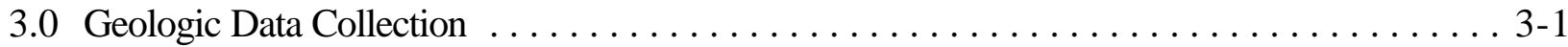

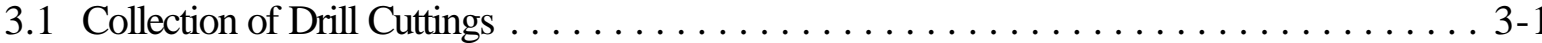

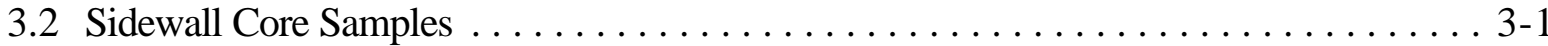

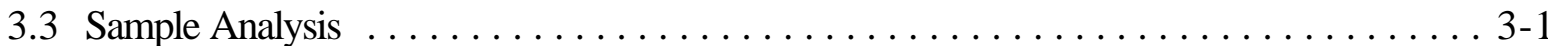

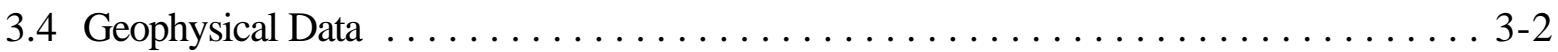

4.0 Geology and Hydrogeology $\ldots \ldots \ldots \ldots \ldots \ldots \ldots \ldots \ldots \ldots \ldots \ldots \ldots \ldots \ldots \ldots \ldots$

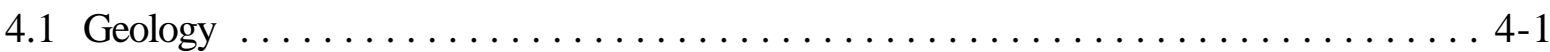

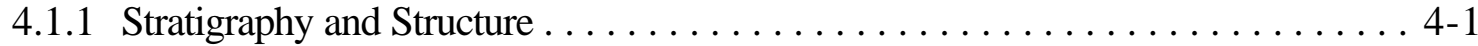

4.1 .2 Alteration . . . . . . . . . . . . . . . . . . . . . . . 4-11

4.2 Predicted Versus Actual Geology $\ldots \ldots \ldots \ldots \ldots \ldots \ldots \ldots \ldots \ldots \ldots \ldots \ldots \ldots \ldots$

4.3 Hydrogeology . . . . . . . . . . . . . . . . . . . . . . . . . . . . . . 4-14 


\section{Table of Contents (Continued)}

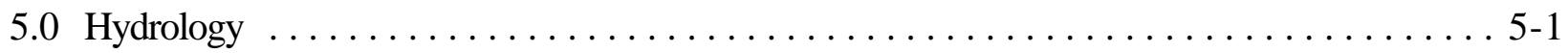

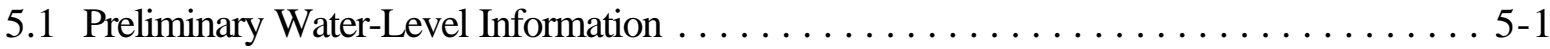

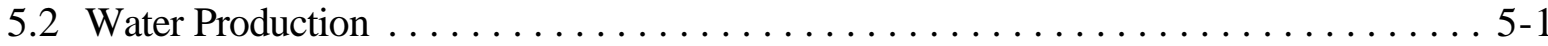

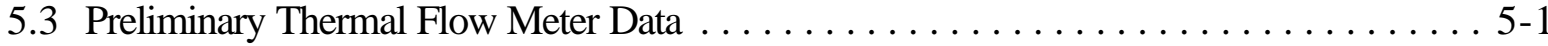

5.4 Preliminary Groundwater Characterization Samples $\ldots \ldots \ldots \ldots \ldots \ldots \ldots \ldots \ldots .2$

6.0 Precompletion and Open-Hole Development $\ldots \ldots \ldots \ldots \ldots \ldots \ldots \ldots \ldots \ldots$ 6-1

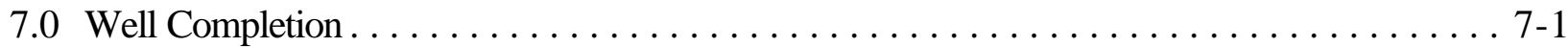

7.1 Introduction $\ldots \ldots \ldots \ldots \ldots \ldots \ldots \ldots \ldots \ldots \ldots \ldots \ldots \ldots \ldots \ldots \ldots \ldots \ldots \ldots, 1$

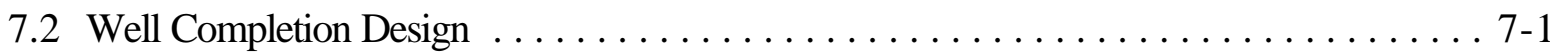

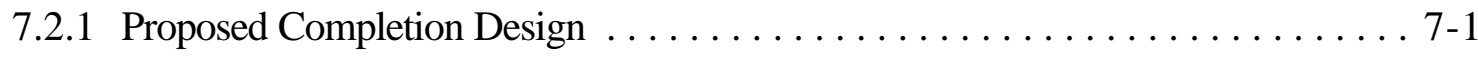

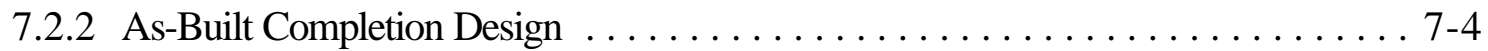

7.2.3 Rationale for Differences between Actual and Proposed Well Design ........ . 7-5

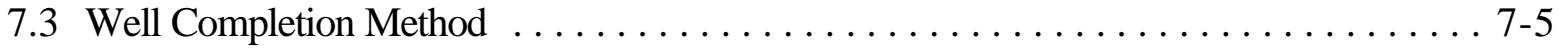

8.0 Actual versus Planned Costs and Scheduling $\ldots \ldots \ldots \ldots \ldots \ldots \ldots \ldots \ldots \ldots \ldots \ldots$ 8-1

9.0 Summary, Recommendations, and Lessons Learned $\ldots \ldots \ldots \ldots \ldots \ldots \ldots \ldots$. $9-1$

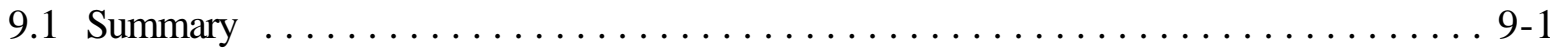

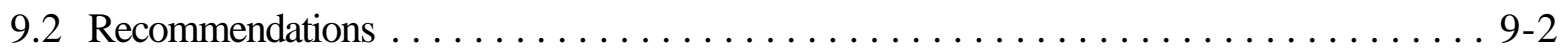

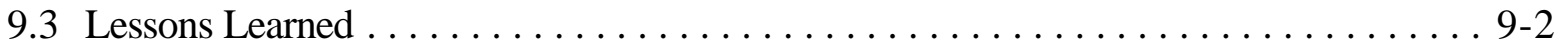

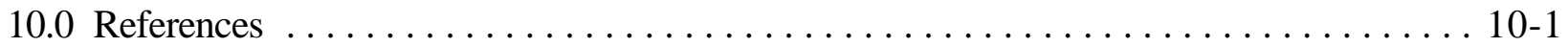

Appendix A - Drilling Data

A-1 Drilling Parameter Log for Well ER-EC-7

A-2 Casing Data for Well ER-EC-7

A-3 Well ER-EC-7 Drilling Fluids and Cement Composition Appendix B - Well ER-EC-7 Fluid Management Data

Well ER-EC-7 Fluid Disposition Reporting Form

Preliminary Analytical Results for Fluid Management Samples at Well ER-EC-7 Appendix C - Detailed Lithologic Log for Well ER-EC-7

Appendix D - Geophysical Logs Run in Well ER-EC-7

Distribution List 


\section{List of Figures}

Number

1-1 Reference Map Showing Location of Well ER-EC-7 . . . . . . . . . . . 1-3

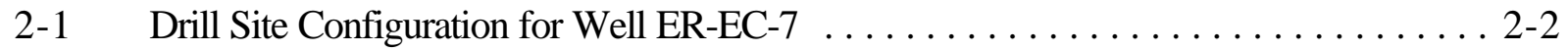

2-2 Well ER-EC-7 Drilling and Completion History $\ldots \ldots \ldots \ldots \ldots \ldots \ldots \ldots \ldots$

4-1 Map of Western Pahute Mesa - Oasis Valley Area Showing Theorized

Locations of Caldera Boundaries . . . . . . . . . . . . . . . . . 4-3

4-2 Surface Geologic Map of the Well ER-EC-7 Site $\ldots \ldots \ldots \ldots \ldots \ldots \ldots \ldots \ldots$. . . . . . .

4-3 Geology and Hydrogeology of Well ER-EC-7 . . . . . . . . . . . . . . 4-9

4-4 Geologic Cross Section A-A' Through Well ER-EC-7 . . . . . . . . . . . . . 4-12

4-5 Predicted and Actual Stratigraphy at Well ER-EC-7 . . . . . . . . . . . 4-13

4-6 Hydrogeologic Cross Section B-B' Through Well ER-EC-7 . . . . . . . . . . . . 4-15

7-1 As-built Completion Schematic for Well ER-EC-7 . . . . . . . . . . . . . 7-2

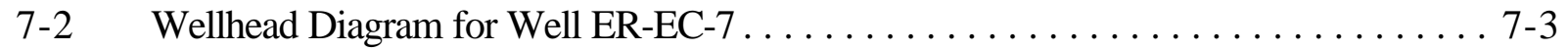

8-1 Planned versus Actual Construction Progress for Well ER-EC-7 . . . . . . . . . . 8-2

8-2 Planned versus Actual Cost for Constructing Well ER-EC-7 . . . . . . . . . 8-3 


\section{List of Tables}

Number

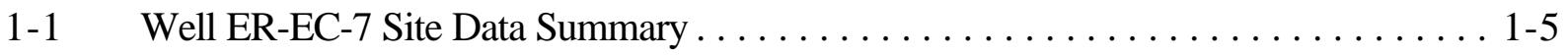

2-1 Abridged Drill Hole Statistics for Well ER-EC-7 . . . . . . . . . . . . 2-4

3-1 Status of Rock Sample Analyses for Well ER-EC-7 . . . . . . . . . . . . . . 3-3

3-2 Well ER-EC-7 Geophysical Log Summary . . . . . . . . . . . . . . . . . . . 3-4

7-1 Well ER-EC-7 Completion String Construction Summary . . . . . . . . . . . 7-4

A-3-1 Well ER-EC-7 Drilling Fluids $\ldots \ldots \ldots \ldots \ldots \ldots \ldots \ldots \ldots \ldots \ldots \ldots \ldots \ldots \ldots \ldots \ldots$

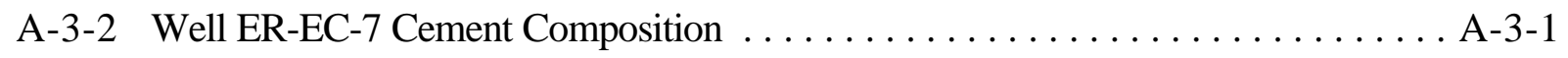

D-1 Well ER-EC-7 Geophysical Logs Presented . . . . . . . . . . . . . . . . D-1 


\section{List of Acronyms and Abbreviations}

\begin{tabular}{|c|c|}
\hline $\mathrm{BN}$ & Bechtel Nevada \\
\hline $\mathrm{C}$ & Celsius \\
\hline $\mathrm{cm}$ & centimeter(s) \\
\hline DOE & U.S. Department of Energy \\
\hline $\mathrm{DOE} / \mathrm{NV}$ & U.S. Department of Energy, Nevada Operations Office \\
\hline DRI & Desert Research Institute \\
\hline $\mathrm{EC}$ & Electrical Conductivity \\
\hline $\mathrm{F}$ & Fahrenheit \\
\hline FMP & Fluid Management Plan \\
\hline $\mathrm{ft}$ & foot (feet) \\
\hline gpm & gallons per minute \\
\hline in. & inch(es) \\
\hline IT & IT Corporation \\
\hline lpm & liters per minute \\
\hline LANL & Los Alamos National Laboratory \\
\hline $\mathrm{LiBr}$ & lithium bromide \\
\hline $\mathrm{m}$ & meter(s) \\
\hline Ma & million years ago \\
\hline NAD & North American Datum \\
\hline NNSA/NSO & National Nuclear Security Administration Nevada Site Office \\
\hline NTS & Nevada Test Site \\
\hline TD & total depth \\
\hline TFM & Thermal Flow Meter \\
\hline TMCC & Timber Mountain caldera complex \\
\hline UDI & United Drilling, Inc. \\
\hline UGTA & Underground Test Area \\
\hline USGS & United States Geological Survey \\
\hline WPM-OV & Western Pahute Mesa - Oasis Valley \\
\hline
\end{tabular}


This page intentionally left blank. 


\subsection{Introduction}

\subsection{Project Description}

Well ER-EC-7 was drilled for the U.S. Department of Energy (DOE) National Nuclear Security Administration Nevada Site Office (NNSA/NSO; formerly Nevada Operations Office, DOE/NV) in support of the Nevada Environmental Restoration Project at the Nevada Test Site (NTS), Nye County, Nevada. Well ER-EC-7 is the seventh in a series of wells drilled as part of the hydrogeologic investigation well program in the Western Pahute Mesa - Oasis Valley (WPM-OV) region of Nye County, Nevada. This program is part of the NNSA/NSO Environmental Restoration Division's Underground Test Area (UGTA) project at the NTS. The goals of the UGTA project include evaluating the nature and extent of contamination in groundwater due to underground nuclear testing and establishing a long-term groundwater monitoring network. As part of the UGTA project, scientists are developing computer models to predict groundwater flow and contaminant migration within and near the NTS. To develop and test these models it is necessary to collect geologic, geophysical, and hydrologic data from new and existing wells to define groundwater migration pathways, migration rates, and quality.

The goal of the WPM-OV program is to collect subsurface geologic and hydrologic data in a large, insufficiently characterized area down-gradient from Pahute Mesa where underground nuclear tests were conducted, and up-gradient from groundwater discharge and withdrawal sites in Oasis Valley northeast of Beatty, Nevada (Figure 1-1). Data from these wells will allow for more accurate modeling of groundwater flow and radionuclide migration in the region. Some of the wells may also function as long-term monitoring wells.

Well ER-EC-7 is located within the Nellis Air Force Range complex, approximately 2.9 kilometers (1.8 miles) west of the Nevada Test Site, south of Timber Mountain (Figure 1-1). The elevation of the dirt-fill drill pad at the wellhead is 1,464.7 meters $(\mathrm{m})(4,805.4$ feet [ft]) above mean sea level. The Nevada State Planar coordinates (North American Datum [NAD] 1983) at the wellhead are

North (N) 6,247,968.6 and East (E) 516,743.7 m (N 20,498,543.7 and E 1,695,350.1 ft). Additional site data are listed in Table 1-1.

IT Corporation (IT) was the principal environmental contractor for the project, and IT personnel collected geologic and hydrologic data during drilling. The drilling company was United Drilling, Incorporated (UDI), a subcontractor to Bechtel Nevada (BN). Site supervision, engineering, construction, inspection, and geologic support were provided by BN. The roles and 
This page intentionally left blank. 


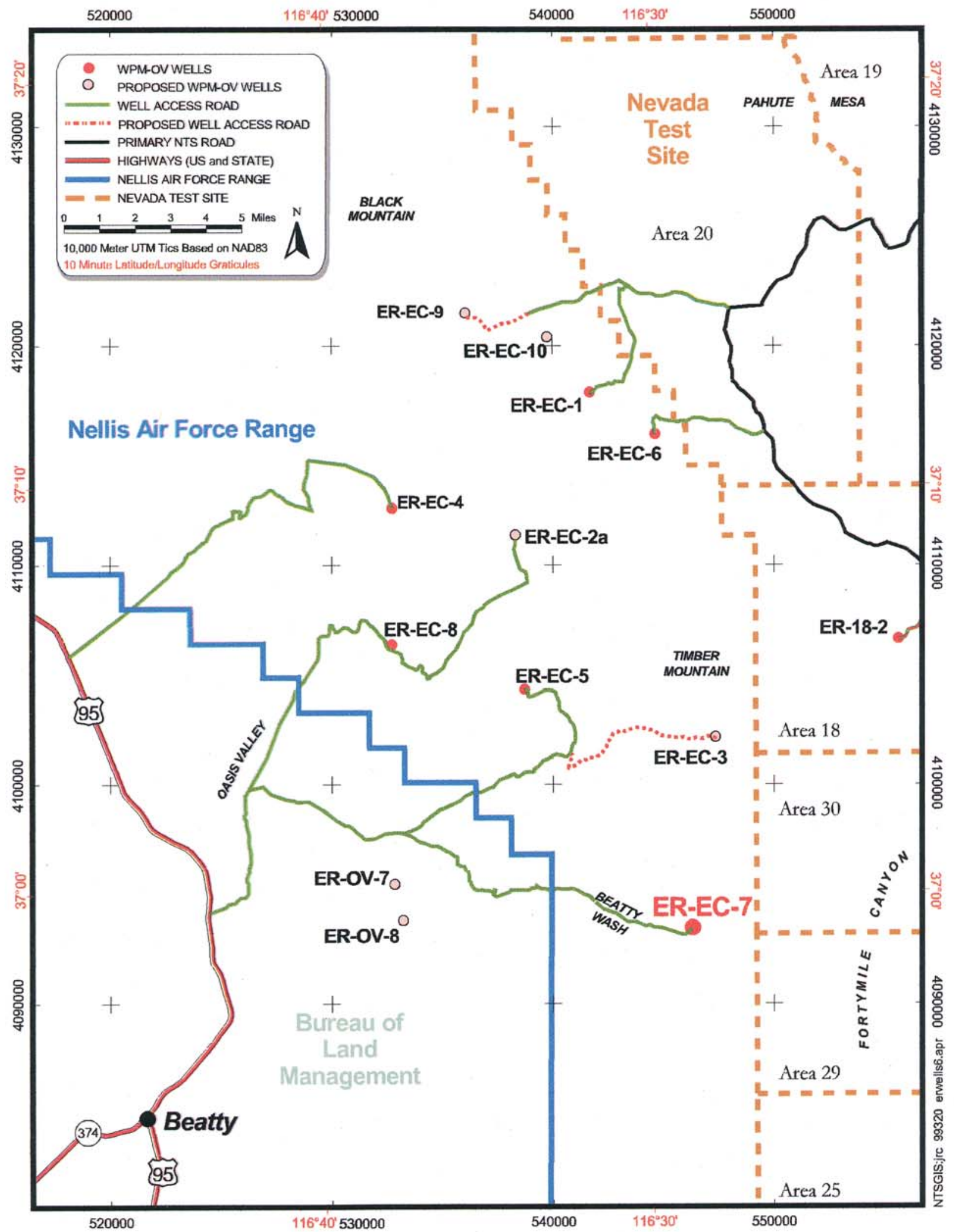

Figure 1-1

Reference Map Showing Location of Well ER-EC-7

(Proposed wells not drilled at time Well ER-EC-7 was drilled.) 
This page intentionally left blank. 


\section{Table 1-1 \\ Well ER-EC-7 Site Data Summary}

\begin{tabular}{|c|c|}
\hline Well Designation & ER-EC-7 \\
\hline Site Coordinates ${ }^{a}$ & $\begin{array}{l}\text { Central Nevada State Planar (NAD 83): } \\
\qquad \begin{array}{l}\text { N 6,247,968.6 m } \quad \text { (N 20,498,543.7 ft) } \\
\text { E 516,743.7 m } \quad(\text { E 1,695,350.1 ft) }\end{array} \\
\text { Central Nevada State Planar (NAD 27): } \\
\text { N 813,542.3 ft } \\
\text { E 555,194.0 ft } \\
\text { Universal Transverse Mercator (Zone 11)(NAD 83) } \\
\text { N 4,093,324.3 m } \\
\text { E 546,403.4 m }\end{array}$ \\
\hline Surface Elevation ${ }^{b}$ & $1,464.7 \mathrm{~m}(4,805.4 \mathrm{ft})$ \\
\hline Drilled Depth & $422.5 \mathrm{~m}(1,386 \mathrm{ft})$ \\
\hline Fluid-Level Depth ${ }^{\mathrm{c}}$ & $227.8 \mathrm{~m}(747.5 \mathrm{ft})$ \\
\hline Fluid-Level Elevation & $1,236.8 \mathrm{~m}(4,057.9 \mathrm{ft})$ \\
\hline
\end{tabular}

\footnotetext{
a Measurement by BN Survey.

b Measurement by BN Survey. Elevation at top of drill pad. 1929 National Geodetic Vertical Datum.

c Measured by IT on August 19, 1999, approximately 20 days after completion string was installed (IT, 1999).
}

responsibilities of these and other contractors involved in the project are described in Contract Number DE-RP-08-95NV11808, and in BN Drilling Work Plan Number D-007-002.99 (BN, 1999b). The UGTA Technical Working Group, a committee of scientists and engineers comprising NNSA/NSO, Lawrence Livermore National Laboratory, Los Alamos National Laboratory (LANL), and contractor personnel, provided additional technical advice during drilling, design, and construction of the well. See FY99 Western Pahute Mesa-Oasis Valley Hydrogeologic Investigation Wells Drilling and Completion Criteria (IT, 1998) for descriptions of the general plan and goals of the WPM-OV project, as well as specific goals for each planned well.

General guidelines for managing fluids used and generated during drilling, completion, and testing of UGTA wells are provided in the UGTA Fluid Management Plan (FMP) (DOE, 1996a), an attachment to the UGTA Waste Management Plan (DOE, 1996b). Estimates of fluid and cuttings production for the WPM-OV holes are given in Appendix $\mathrm{N}$ of the drilling and completion criteria document for the 
WPM-OV project (IT, 1998), along with sampling requirements and contingency plans for management of any hazardous waste produced. All activities were conducted according to the Nevada Environmental Restoration Project Health and Safety Plan (DOE, 1998), and the Site-Specific Health and Safety Plan for WPM-OV Investigation Wells (BN, 1999a).

This report presents construction data and summarizes scientific data gathered during drilling and installation of the completion string. Some of the information in this report is preliminary and unprocessed, but is being released with drilling and completion data for convenient reference. A well data report prepared by IT (IT, 1999) contains additional information on fluid management, waste management, and environmental compliance. Information on well development, aquifer testing, and groundwater analytical sampling will be disseminated after any such work is performed.

\subsection{Objectives}

The primary purpose of Well ER-EC-7 is to provide information about hydrostratigraphic units, geologic structures, and bulk hydraulic properties in this part of the WPM-OV area. Well-specific scientific objectives, as discussed in Appendix G of the drilling criteria document (IT, 1998), include the following:

! Determine water levels to characterize the local potentiometric surface and groundwater flow.

! Investigate a possible groundwater flow path south from Pahute Mesa, and along the east and south sides of Timber Mountain

! Characterize hydraulic properties south of an east-west striking transverse zone (see Section 4.1 .1 of this report).

Some of these objectives will not be met until additional work, outside the scope of this report, is completed, including installing a pump and conducting hydraulic testing, and analyzing geology and hydrology data from this and other planned wells in the WPM-OV area.

\subsection{Project Summary}

This section summarizes Well ER-EC-7 construction operations; the details are provided in sections 2 through 8 of this report. 
The surface conductor hole was constructed by augering a 91.4-centimeter (cm) (36-inch [in.]) diameter hole to a depth of $12.5 \mathrm{~m}$ (41 ft) and installing a string of 20-in. casing. This conductor casing was cemented in place on July 22, 1999. Drilling of the main hole with a 171/2-in. rotary bit, using airfoam and polymer in conventional circulation, began on July 30, 1999. A suitable depth to set casing was reached at $266.7 \mathrm{~m}(875 \mathrm{ft})$, and $13 \mathrm{~d}$-in. surface casing was landed at $265.8 \mathrm{~m}(872 \mathrm{ft})$ on August 3, 1999, approximately $38.1 \mathrm{~m}$ (125 ft) below the static water level. Drilling continued with a 121/4-in. bit to a total depth (TD) of $422.5 \mathrm{~m}$ (1,386 ft), which was reached on August 6, 1999. The planned TD of $762.0 \mathrm{~m}(2,500 \mathrm{ft})$ was not reached due to borehole instability problems.

Water production was first noted at the depth of approximately $229.8 \mathrm{~m}(754 \mathrm{ft})$, and reached a maximum of approximately 5,111 liters per minute (lpm) (1,350 gallons per minute [gpm]) near the bottom of the hole. Twenty days after installation of the completion string, the fluid level was tagged at the depth of $227.8 \mathrm{~m}$ (747.5 ft). No radionuclides above background levels were encountered during drilling of Well ER-EC-7.

Composite drill cuttings were collected every $3.0 \mathrm{~m}$ (10 ft) from $12.2 \mathrm{~m}$ (40 ft) to TD. No sidewall core samples were taken from Well ER-EC-7. Open-hole geophysical logging of the well was conducted to help verify the geology and characterize the hydrology of the rocks; some logs also aided in the construction of the well by indicating borehole volume and condition, and cement location. The well penetrated lava and bedded tuff of the Volcanics of Fortymile Canyon Group, including the Beatty Wash Formation, rhyolite of Chukar Canyon, and tuff of Leadfield Road.

A single completion string was installed in Well ER-EC-7 on August 9, 1999. A string of 51/2-in. fiberglass production casing was landed at $398.1 \mathrm{~m}(1,306.0 \mathrm{ft})$. The bull-nosed string has two slotted

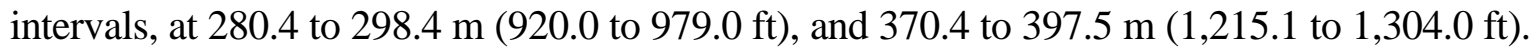
Internally epoxy-coated, 7e -in. carbon-steel casing extends (via crossover subs) from the top of the $51 / 2$-in. casing at $271.4 \mathrm{~m}(890.4 \mathrm{ft})$ to the ground surface. The completion string was gravel-packed across the slotted intervals and the remaining annular space was filled with gravel, sand, and cement to the depth of $172.8 \mathrm{~m}(567 \mathrm{ft})$ on August 10, 1999. No pump was installed at the time of completion. 


\subsection{Project Manager}

Inquiries concerning Well ER-EC-7 should be directed to the UGTA Project Manager at:

U.S. Department of Energy

National Nuclear Security Administration

Nevada Site Office

Environmental Restoration Division

Post Office Box 98518

Las Vegas, Nevada 89193-8518 


\subsection{Drilling Summary}

This section contains detailed descriptions of the drilling process and fluid management issues.

\subsection{Introduction}

The general drilling requirements for all WPM-OV wells are described in FY99 Western Pahute Mesa-Oasis Valley Hydrogeologic Investigation Wells Drilling and Completion Criteria (IT, 1998), which also includes criteria for Well ER-EC-7 in Appendix G. Specific requirements for Well ER-EC-7 were outlined in Drilling Work Plan Number D-007-002.99 (BN, 1999b). The drilling history (Section 2.2) was compiled primarily from BN daily drilling reports. Figure 2-1 shows the layout of the drill site. Figure 2-2 is a chart of the drilling and completion history for Well ER-EC-7. A summary of drilling statistics for the well is given in Table 2-1. Fluid management information (Section 2.4) was obtained primarily from IT's well data report (IT, 1999).

\subsection{Drilling History}

Field operations at Well ER-EC-7 began on July 20 to 22, 1999, with the construction of the conductor hole. A BN drill crew used an auger rig to drill a 66.0-cm (26-in.) diameter hole to the

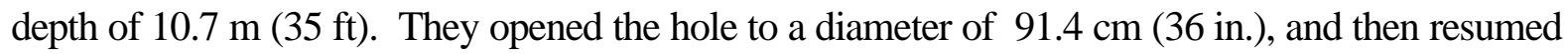
augering a 66.0-cm (26-in.) hole from 10.7 to $12.5 \mathrm{~m}$ (35 to $41 \mathrm{ft}$ ). After the lower portion of the borehole was reamed to a diameter of $91.4 \mathrm{~cm}$ (36 in.), a string of 20-in. conductor casing was set

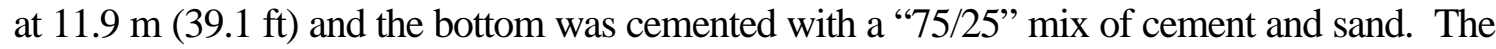
annulus of the casing was then cemented to the ground surface with a combination of $75 / 25$ mix and neat cement. The site was inactive until UDI began hauling equipment from Well ER-EC-8 on July 28, 1999. The UDI crews rigged up the Wilson Mogul 42B rig on July 28-30, 1999, and tagged cement inside the conductor casing at the depth of $10.4 \mathrm{~m}(34 \mathrm{ft})$.

Drilling of the main hole with a 171/2-in. button bit began on July 30, 1999, using an air-water-foam drilling fluid ("air-foam") with a polymer additive in conventional (direct) circulation. The first water production was noted by IT personnel at a depth of approximately $229.8 \mathrm{~m}$ (754 ft).

As a precaution against sloughing of the upper section of unsaturated volcanic rocks, it was decided to install surface casing when a competent formation for supporting the casing was reached. 


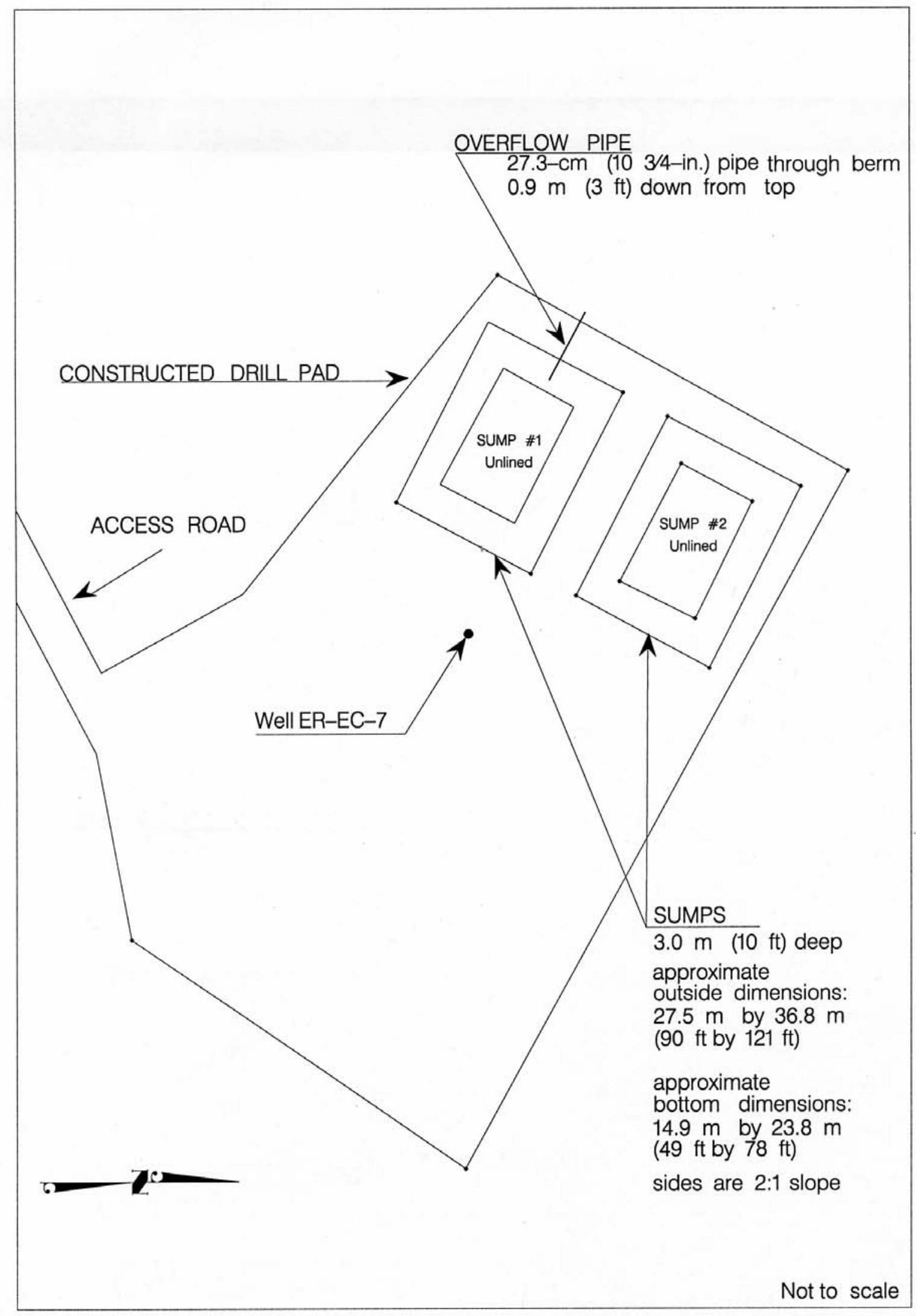

Figure 2-1

Drill-Site Configuration for Well ER-EC-7 


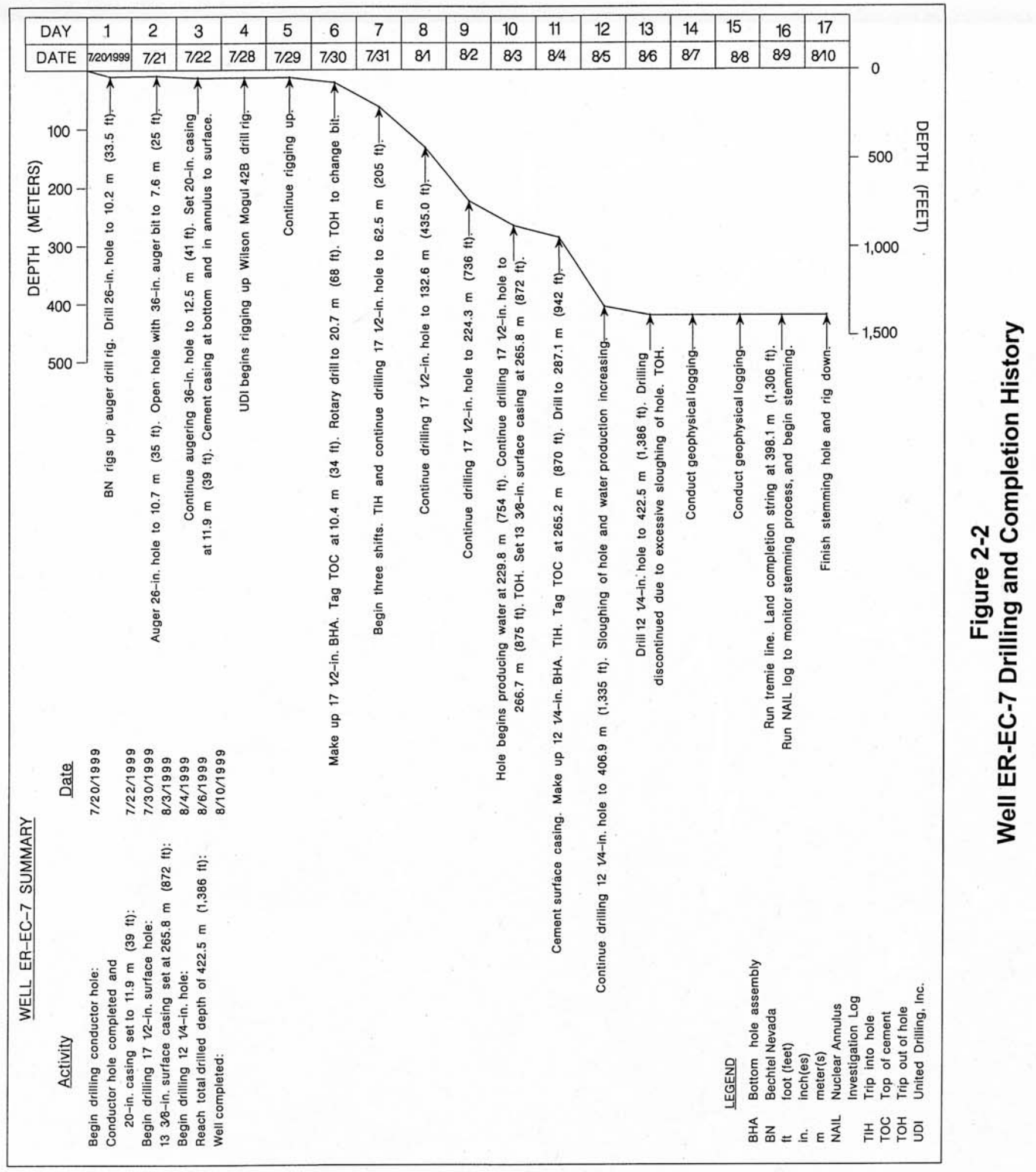




\section{Table 2-1}

\section{Abridged Drill Hole Statistics for Well ER-EC-7}

\begin{tabular}{|c|c|c|}
\hline $\begin{array}{l}\text { LOCATION DATA: } \\
\text { Wellhead Coordinates: } \\
\text { Surface Elevation }{ }^{\text {a: }}\end{array}$ & \multicolumn{2}{|c|}{ 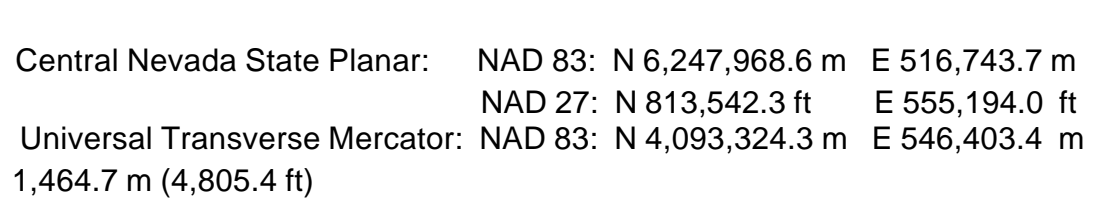 } \\
\hline \multicolumn{3}{|l|}{ DRILLING DATA: } \\
\hline Spud Date: & \multicolumn{2}{|c|}{ 7/30/1999 (main hole drilled with Wilson Mogul 42B rig) } \\
\hline $\begin{array}{l}\text { Total Depth (TD): } \\
\text { Date TD Reached: }\end{array}$ & \multicolumn{2}{|c|}{$\begin{array}{l}422.5 \mathrm{~m}(1,386 \mathrm{ft}) \\
8 / 6 / 1999\end{array}$} \\
\hline $\begin{array}{l}\text { Date Well Completed }{ }^{\mathrm{b}} \text { : } \\
\text { Hole Diameter: }\end{array}$ & \multicolumn{2}{|c|}{$\begin{array}{l}\text { 8/10/1999 } \\
91.4 \mathrm{~cm} \text { (36 in.) from surface to } 12.5 \mathrm{~m}(41 \mathrm{ft} .) ; 44.5 \mathrm{~cm}(17.5 \mathrm{in} .) \text { from } 12.5\end{array}$} \\
\hline & \multicolumn{2}{|c|}{$\begin{array}{l}\text { to } 266.7 \mathrm{~m}(41 \text { to } 875 \mathrm{ft}) ; 31.1 \mathrm{~cm}(12.25 \mathrm{in} \text {.) from } 266.7 \mathrm{~m}(875 \mathrm{ft}) \text { to TD of } \\
422.5 \mathrm{~m}(1,386 \mathrm{ft}) .\end{array}$} \\
\hline Drilling Techniques: & \multicolumn{2}{|c|}{$\begin{array}{l}\text { Dry-hole auger from surface to } 12.5 \mathrm{~m}(41 \mathrm{ft} \text {.); rotary drilling using air-foam } \\
\text { and polymer in direct circulation with } 171 / 2 \text {-in. bit from } 12.5 \text { to } 266.7 \mathrm{~m} \text { ( } 41 \text { to } \\
875 \mathrm{ft}) \text {, and with a } 12^{1 / 4}-\mathrm{in} \text {. bit to the TD of } 422.5 \mathrm{~m}(1,386 \mathrm{ft}) \text {. }\end{array}$} \\
\hline CASING DATA: & \multicolumn{2}{|c|}{$\begin{array}{l}\text { 20-in. conductor casing, surface to } 11.0 \mathrm{~m}(36 \mathrm{ft}) ; 13 \mathrm{~d} \text {-in. surface casing, } \\
\text { surface to } 265.8 \mathrm{~m}(872 \mathrm{ft}) \text {. }\end{array}$} \\
\hline \multicolumn{3}{|c|}{$\begin{array}{l}\text { WELL COMPLETION DATA: } \\
\text { The completion string consists of } 7 \mathrm{e} \text {-in. carbon-steel casing with an internal epoxy coating, connected } \\
\text { to } 5.57 \text {-in. Fiberglass casing via an internally coated carbon-steel crossover sub. The carbon-steel } \\
\text { casing extends through the unsaturated zone approximately } 42.7 \mathrm{~m}(140 \mathrm{ft} \text { ) into the top of the saturated } \\
\text { zone. The } 14.15-\mathrm{cm} \text { (5.57-in.) outside-diameter casing has a } 12.07-\mathrm{cm}(4.75-\text {-in.) inside diameter, is } \\
\text { bull-nosed, and has two slotted intervals (listed below) that each consist of two to three consecutive } \\
\text { slotted joints. Detailed data for the completion intervals are provided in Section } 7 \text { of this report. }\end{array}$} \\
\hline Total Depth: & $422.5 \mathrm{~m}(1,386 \mathrm{ft})$ & \\
\hline Depth of Slotted Sections & $\begin{array}{l}280.4 \text { to } 298.4 \mathrm{~m} \\
(920.0 \text { to } 979.0 \mathrm{ft})\end{array}$ & $\begin{array}{l}370.4 \text { to } 397.5 \mathrm{~m} \\
(1,215.1 \text { to } 1,304.0 \mathrm{ft})\end{array}$ \\
\hline Depth of Sand Packs: & $\begin{array}{l}272.8 \text { to } 278.0 \mathrm{~m} \\
(895 \text { to } 912 \mathrm{ft})\end{array}$ & $\begin{array}{l}351.4 \text { to } 360.9 \mathrm{~m} \\
(1,153 \text { to } 1,184 \mathrm{ft})\end{array}$ \\
\hline Depth of Gravel Packs: & $\begin{array}{l}278.0 \text { to } 312.1 \mathrm{~m} \\
(912 \text { to } 1,024 \mathrm{ft})\end{array}$ & $\begin{array}{l}360.9 \text { to } 399.3 \mathrm{~m} \\
(1,184 \text { to } 1,310 \mathrm{ft})\end{array}$ \\
\hline Depth of Pump: & \multicolumn{2}{|c|}{ None installed at time of completion. } \\
\hline Water Depth ${ }^{\mathrm{c}}$ : & \multicolumn{2}{|l|}{$227.8 \mathrm{~m}(747.5 \mathrm{ft})$} \\
\hline DRILLING CONTRACTOR: & \multicolumn{2}{|l|}{ United Drilling, Inc. } \\
\hline GEOPHYSICAL LOGS BY: & \multicolumn{2}{|c|}{$\begin{array}{l}\text { Schlumberger Logging Services, Colog, Inc. Desert Research Institute, } \\
\text { Gyrodata }\end{array}$} \\
\hline SURVEYING CONTRACTOR: & Bechtel Nevada & \\
\hline
\end{tabular}

a Elevation of ground level at wellhead. 1929 National Geodetic Vertical Datum.

b Date completion string was cemented. Pump will be installed at a later date as needed.

C Measured by IT on August 30, 1999, approximately 20 days after completion string was installed (IT, 1999). 
The decision was made to stop and set casing on August 3, 1999, at a depth of $266.7 \mathrm{~m}$ (875 ft), within a lava unit. At this depth the hole was producing water at a rate of approximately $114 \mathrm{lpm}$ (30 gpm). The drillers circulated fluid to clean and condition the hole, pulled the drill string a short distance off the bottom, and waited about thirty minutes before tagging bottom again. No fill was found, and the drillers pulled the drill string from the hole. Geophysical logging was not conducted prior to installation of casing.

A casing subcontractor landed $13 \mathrm{~d}$-in. casing with centralizers installed above the float shoe, at the middle and top of the first joint, and at the top of the second joint, and with a stab-in float collar at

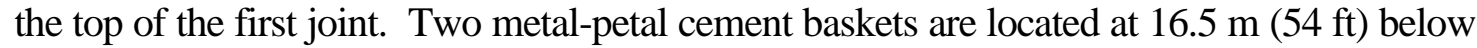
ground level. The casing was landed at a depth of $265.8 \mathrm{~m}$ (872 ft) on August 3, 1999, and after the stab-in sub was seated in the float collar, the seal was checked by pumping air down the drill pipe. Pre-flush clear water was pumped down the casing and the annulus prior to cementing. Type II cement was pumped inside the casing through the stab-in sub, followed by water to displace the cement into the annulus. The top of cement in the annulus was later determined by geophysical logs to be at the depth of approximately $207.6 \mathrm{~m}(681 \mathrm{ft})$. After the drill pipe was pulled from the hole, cement was dropped on the cement baskets and allowed to harden before the remaining annular space was cemented to ground level. Cementing of the surface casing was completed on August 4, 1999. The top of cement inside the casing was tagged at $265.2 \mathrm{~m}$ (870 ft) when drilling resumed.

A 121/4-in. bit and air-foam/polymer drilling fluid were used to drill the remainder of the hole. Cement was drilled from 265.2 to $266.7 \mathrm{~m}$ (870 to $875 \mathrm{ft}$ ), below which depth drilling continued into the formation.

The amounts of polymer and foaming agent in the drilling fluid and the fluid injection rate were adjusted as necessary during drilling to maintain superior circulation and penetration rate, and to minimize sloughing of material from the borehole wall. Fill encountered (due to sloughing) was minimal during drilling of the 171/2-in. surface hole and through most of the drilling of the 121/4-in. main hole: little to no fill was found when drilling was stopped to add joints of drill pipe ("making connections"), though $1.5 \mathrm{~m}$ (5 ft) of fill was encountered on a connection at $100.3 \mathrm{~m}(329 \mathrm{ft})$. However, below a depth of about $396.2 \mathrm{~m}(1,300 \mathrm{ft})$, increasing amounts of fill of up to $3.0 \mathrm{~m}$ $(10 \mathrm{ft})$ were encountered. At the depth of $422.5 \mathrm{~m}(1,386 \mathrm{ft}), 9.1 \mathrm{~m}(30 \mathrm{ft})$ was encountered on an 
attempted connection, and the hole became tight and sloughing increased. The drillers pulled the bit up into the casing and awaited orders. At 1500 hours on August 6, 1999, the decision was made to stop drilling, leaving $422.5 \mathrm{~m}$ (1,386 ft) as the TD of Well ER-EC-7, $339.5 \mathrm{~m}(1,114 \mathrm{ft})$ short of the planned TD of $762.0 \mathrm{~m}(2,500 \mathrm{ft})$.

Immediately after the decision was made to terminate drilling, the drillers circulated fluid to condition the hole before geophysical logging, which took place on August 7 and 8, 1999. Installation of the completion string began on August 9, 1999. Demobilization from the Well ER-EC-7 site began after gravel-packing and cementing were completed on August 10, 1999.

The directional survey run in the well on October 18, 1999, indicates that at the lowest surveyed depth of $396.2 \mathrm{~m}(1,300 \mathrm{ft})$ the hole had drifted $5.3 \mathrm{~m}(17.5 \mathrm{ft})$ to the northwest of the collar location, and that the hole is relatively straight (no "dog legs").

A graphical depiction of drilling parameters including penetration rate, revolutions per minute, pump pressure, and weight on the bit is presented in Appendix A-1. See Appendix A-2 for a listing of casing materials. Drilling fluids and cements used in Well ER-EC-7 are listed in Appendix A-3.

\subsection{Drilling Problems}

The most significant problem encountered in the drilling of Well ER-EC-7 was the excessive sloughing of the borehole wall while drilling within an altered lava flow. Below the depth of about

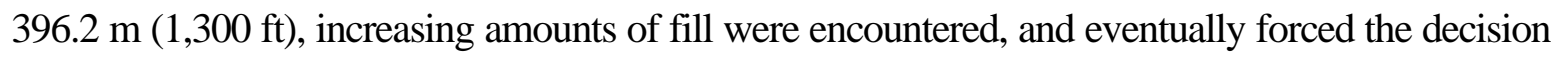
to terminate drilling. Approximately $23.2 \mathrm{~m}$ (76 ft) of fill remained in the bottom of the hole prior to geophysical logging and installation of the completion string. Because no geophysical logs were obtained in the problem interval, it is not possible to verify the presence of any geology-related problem such as excessive fracturing. The shallower-than-planned TD required that the proposed completion design be modified. The early termination of drilling resulted in a delay of $181 / 2$ hours spent waiting for logging companies to mobilize on short notice.

\subsection{Fluid Management}

Drilling effluent was monitored according to the methods prescribed in the UGTA FMP (DOE, 1996a). The air-foam/polymer drill fluid was circulated down the inside of the drill string and back up the hole through the annulus (conventional or direct circulation) and then discharged into a sump. Water used to prepare drilling fluids came from the Coffer Well, approximately 16 kilometers 
(10 miles) north-northeast of Beatty, Nevada, and a lithium bromide (LiBr) tracer was added as a means of estimating groundwater production.

To manage the expected water production, two sumps were constructed prior to drilling (Figure 2-1). No contaminants were expected during drilling at this site, so neither sump was lined prior to drilling. Sump 1 was constructed with an overflow pipe that would allow discharge to the ground surface when fluid in the sump reached the level of the pipe. Most of the effluent produced during drilling of Well ER-EC-7 was routed to sump 1; sump 2 was used to contain the smaller amounts of fluid produced whenever drilling was stopped to add drill pipe. No fluid was allowed to discharge to the ground surface until compliance with FMP criteria was demonstrated through analysis of fluid from the sump. Samples of drilling effluent were tested on site hourly for the presence of tritium, and every eight hours for lead. The on-site monitoring results indicate that tritium remained at background levels and lead was not detected during the entire drilling operation (IT, 1999).

On-site monitoring data were verified by an off-site laboratory. After the results of the off-site analysis of a fluid sample taken from sump 1 on August 3, 1999, indicated values for analytes below the allowable FMP discharge levels, fluid was allowed to flow from sump 1 to the ground surface via the overflow pipe. At the conclusion of drilling operations sump samples were again collected to determine the ultimate disposition of the drilling fluids. Two samples were collected from sump 1 and one from sump 2. Water-quality data from the FMP samples are given in Appendix B.

The results of analyses of samples of drilling fluid collected at Well ER-EC-7 during drilling operations indicate that all fluid quality objectives were met, as shown on the fluid management reporting form dated August 31, 1999 (Appendix B). The form lists volumes of solids (drill cuttings) and fluids produced during well-construction operations, Stages I and II (i.e., vadose- and saturated-zone drilling; well development and aquifer testing will be conducted at a later date). The volume of solids produced was calculated using the diameter of the borehole (from caliper logs) and the depth drilled, and includes added volume attributed to a rock bulking factor. The volumes of fluids listed on the report are estimates of total fluid production, and do not account for any infiltration or evaporation of fluids from the sumps. 
This page intentionally left blank. 


\subsection{Geologic Data Collection}

This section describes the sources of geologic data obtained from Well ER-EC-7 and the methods of data collection. Improving the understanding of the subsurface structure, stratigraphy, and hydrogeology in the area southwest of Pahute Mesa was among the primary objectives of Well ER-EC-7, so the proper collection of geologic and hydrogeologic data from Well ER-EC-7 was considered fundamental to successful completion of the project.

Geologic data collected at Well ER-EC-7 consist of drill cuttings and geophysical logs. Data collection, sampling, transfer, and documentation activities were performed according to applicable contractor procedures.

\subsection{Collection of Drill Cuttings}

Composite drill cuttings were collected from Well ER-EC-7 at 3.05-m (10-ft) intervals as drilling progressed from the depth of $12.2 \mathrm{~m}(40 \mathrm{ft})$ to the TD of the well at $422.5 \mathrm{~m}(1,386 \mathrm{ft})$. Triplicate samples were collected from 134 intervals, and in addition, the IT field representative collected two sets of reference samples from each of the cuttings intervals. One set was examined at the drill site for use in preparing field lithologic descriptions, and remains in the custody of IT (now StollerNavarro Joint Venture, IT's successor). The other set was sent to R. G. Warren at LANL where it remains. All other samples (i.e., three sets of 134 samples) are stored under secure, environmentally controlled conditions at the U.S. Geological Survey (USGS) Geologic Data Center and Core Library in Mercury, Nevada. One of these sample sets was sealed with custody tape at the rig site and remains sealed as an archive sample; one set was left unsealed in the original sample containers; and the third set was washed and stored according to standard USGS Core Library procedures.

\subsection{Sidewall Core Samples}

No attempt was made to collect sidewall core samples from Well ER-EC-7

\subsection{Sample Analysis}

Ten samples of drill cuttings from various depths in Well ER-EC-7 were submitted to the LANL Earth and Environmental Sciences Division - Geology and Geochemistry laboratories for petrographic, mineralogic, and chemical analyses to aid in stratigraphic identification and for 
characterization of mineral alteration. All planned analyses have been completed, as shown on Table 3-1, which lists the analyses by sample depth.

\subsection{Geophysical Data}

Geophysical logs were run to further characterize the lithology, structure, and water content of the rocks encountered. In addition, logs were run to evaluate borehole conditions, to determine the fluid levels during the course of drilling, and to monitor completion progress. As planned, geophysical logging was conducted after drilling was complete. Surface casing had already been installed to the depth of $265.8 \mathrm{~m}$ (872 ft), which precluded the use of some types of logs in the upper, unsaturated part of the borehole. The caliper log, thermal flow log, chemistry log, digital array sonic log, dual laterolog, and ultrasonic borehole imager log were run only in the open, saturated interval. The density, temperature, epithermal neutron, and natural gamma ray logs were run in both the cased, unsaturated interval and the lower saturated interval. A nuclear annulus investigation log was used to monitor the stemming process during well construction, and to document the location of cement behind the surface casing. A complete listing of the logs, dates run, depths and service companies is provided in Table 3-2. The logs are available from BN in Mercury, Nevada, and copies are on file at the offices of Stoller-Navarro Joint Venture in Las Vegas, Nevada.

The overall quality of the geophysical data collected was good except where borehole conditions caused degradation of the some of the proximity-dependent logs (such as density). Preliminary geophysical data from the logs are reproduced in Appendix D. 
Table 3-1

Status of Rock Sample Analyses for Well ER-EC-7

\begin{tabular}{|c|c|c|c|c|c|c|}
\hline \multirow{3}{*}{$\begin{array}{c}\text { Depth }^{\text {a }} \\
\text { meters (feet) }\end{array}$} & \multirow{3}{*}{$\begin{array}{l}\text { Sample } \\
\text { Type }^{\text {b }}\end{array}$} & \multicolumn{5}{|c|}{ Analyses Performed ${ }^{c}$} \\
\hline & & \multirow{2}{*}{$\begin{array}{c}\text { Petrographic } \\
\text { PTS }\end{array}$} & \multicolumn{2}{|c|}{ Mineralogic } & \multicolumn{2}{|c|}{ Chemical } \\
\hline & & & MP & XRD & XRF & $\mathrm{Fe}^{2+} / \mathrm{Fe}^{3+}$ \\
\hline $24.4(80)$ & DA & $\mathrm{C}$ & NP & C & $\mathrm{C}$ & C \\
\hline $307.8(1,010)$ & DA & C & NP & C & C & C \\
\hline $313.9(1,030)$ & DA & C & NP & C & C & C \\
\hline $323.1(1,060)$ & DA & C & NP & C & $\mathrm{C}$ & C \\
\hline $344.4(1,130)$ & DA & $\mathrm{C}$ & C & C & $\mathrm{C}$ & C \\
\hline $359.7(1,180)$ & DA & $\mathrm{C}$ & NP & C & C & C \\
\hline $374.9(1,230)$ & DA & C & NP & C & C & C \\
\hline $393.2(1,290)$ & DA & C & NP & $\mathrm{C}$ & $\mathrm{C}$ & $\mathrm{C}$ \\
\hline $402.3(1,320)$ & DA & C & C & C & C & $\mathrm{C}$ \\
\hline $420.6(1,380)$ & DA & C & NP & C & C & C \\
\hline
\end{tabular}

a Depth represents base of 3.0-m (10-ft) sample interval.

b $\quad$ DA $=$ drill cuttings that represent lithologic character of interval.

C $\quad \mathbf{P T S}=$ polished thin section; $\mathbf{M P}=$ electron microprobe; $\mathbf{X R D}=\mathbf{x}$-ray diffraction; $\mathbf{X R F}=\mathrm{X}$-ray fluorescence; $\mathrm{Fe}^{2+} / \mathrm{Fe}^{3+}=$ wet chemical analysis for iron. $\mathbf{N P}=$ analysis not performed; $\mathbf{C}=$ analysis complete. 
Table 3-2

Well ER-EC-7 Geophysical Log Summary

\begin{tabular}{|c|c|c|c|c|c|c|}
\hline Geophysical Log Type a & Log Purpose & $\begin{array}{l}\text { Logging } \\
\text { Service }\end{array}$ & $\begin{array}{l}\text { Date } \\
\text { Logged }\end{array}$ & Run Number & $\begin{array}{l}\text { Bottom of } \\
\text { Logged } \\
\text { Interval }^{b} \\
\text { meters (feet) }\end{array}$ & $\begin{array}{l}\text { Top of Logged } \\
\text { Interval } \\
\text { meters (feet) }\end{array}$ \\
\hline Temperature/Gamma Ray & $\begin{array}{l}\text { Saturated zone: groundwater } \\
\text { temperature/stratigraphic } \\
\text { correlation }\end{array}$ & Schlumberger & 08/08/1999 & TL-1/SGR-1 & $382.8(1,256)$ & $131.4(431)$ \\
\hline * Natural Gamma Ray Spectroscopy & $\begin{array}{l}\text { Stratigraphic correlation, } \\
\text { mineralogy, natural and man- } \\
\text { made radiation }\end{array}$ & Schlumberger & 08/08/1999 & SGR-1 & $386.5(1,268)$ & 0 \\
\hline * Four Arm Caliper/Gamma Ray & $\begin{array}{l}\text { Borehole conditions, cement } \\
\text { volume calculation/ } \\
\text { stratigraphic correlation }\end{array}$ & Schlumberger & 08/08/1999 & CA4-1/GR-1 & $399.9(1,312)$ & $245.4(805)$ \\
\hline $\begin{array}{l}\text { *Epithermal Neutron/Density/ } \\
\text { Gamma Ray/ Caliper }\end{array}$ & $\begin{array}{l}\text { Total water content/lithologic } \\
\text { determination/stratigraphic } \\
\text { correlation/borehole conditions }\end{array}$ & Schlumberger & 08/08/1999 & $\begin{array}{l}\text { ENP-1/CDL-1/ } \\
\text { GR-2/CAL-1 }\end{array}$ & $398.7(1,308)$ & 0 \\
\hline $\begin{array}{l}\text { * Dual Laterolog/ *Spontaneous } \\
\text { Potential/Gamma Ray }\end{array}$ & $\begin{array}{l}\text { Saturated zone: water saturation/ } \\
\text { stratigraphic correlation }\end{array}$ & Schlumberger & 08/08/1999 & DLL-1/ SP-1/GR-3 & $394.7(1,295)$ & $265.5(871)$ \\
\hline $\begin{array}{l}\text { Gamma Ray/Digital Array Sonic } \\
\text { Wave-form and variable density }\end{array}$ & $\begin{array}{l}\text { Saturated zone: } \\
\text { Porosity, lithologic determination }\end{array}$ & Schlumberger & 08/08/1999 & AC-1/GR4 & $393.8(1,292)$ & $258.5(848)$ \\
\hline Ultrasonic Borehole Imager & $\begin{array}{l}\text { Saturated zone: lithologic } \\
\text { characterization, fracture and } \\
\text { void analysis. }\end{array}$ & Schlumberger & 08/08/1999 & BHTV-1 & $398.7(1,308)$ & $265.5(871)$ \\
\hline * Thermal Flow Log & $\begin{array}{l}\text { Rate and direction of groundwater } \\
\text { flow in borehole }\end{array}$ & $\begin{array}{l}\text { Desert } \\
\text { Research } \\
\text { Institute }\end{array}$ & 08/07/1999 & 1 & $397.8(1,305)$ & $257.6(845)$ \\
\hline * Chemistry/Temperature Log & $\begin{array}{l}\text { Groundwater chemistry and } \\
\text { temperature, formation } \\
\text { transmissivity }\end{array}$ & $\begin{array}{l}\text { Desert } \\
\text { Research } \\
\text { Institute }\end{array}$ & 08/07/1999 & 1 & $400.5(1,314)$ & $228.0(748)$ \\
\hline Nuclear Annulus Investigation Log & Well construction monitoring & Colog & $\begin{array}{l}\text { 08/09- } \\
10 / 1999\end{array}$ & AIN-1 & $398.7(1,308)$ & $2.4(8)$ \\
\hline Three-arm caliper & $\begin{array}{l}\text { Borehole conditions. Cement } \\
\text { volume calculations. }\end{array}$ & $\begin{array}{l}\text { Desert } \\
\text { Research } \\
\text { Institute }\end{array}$ & 08/07/1999 & 1 & $401.1(1,316)$ & $259.4(851)$ \\
\hline Gyroscopic Directional Survey & Borehole deviation & Gyrodata & 10/18/1999 & 1 & $396.2(1,300)$ & 0 \\
\hline
\end{tabular}

a Logs presented in geophysical log summary, Appendix D, are indicated by *.

b Depth below ground surface. 


\subsection{Geology and Hydrogeology}

This section summarizes the geology and hydrogeology of Well ER-EC-7. Bechtel Nevada geologists prepared the detailed lithologic descriptions presented in Appendix C, incorporating information from field lithologic descriptions by IT well-site geologists and geophysical log data. Stratigraphic assignments and identification of alteration mineralogy presented here are based primarily on mineralogic and chemical data and interpretations provided by R. G. Warren (LANL) (Warren, 2000).

Interpretations of data from this well have been incorporated into the hydrostratigraphic framework model for the Pahute Mesa - Oasis Valley area (BN, 2002)

\subsection{Geology}

This section is subdivided into discussions of the stratigraphic section and structural features interpreted from Well ER-EC-7 data, followed by a discussion of alteration noted in samples from the well.

\subsubsection{Stratigraphy and Structure}

Well ER-EC-7 is located within the southern moat area of the Timber Mountain caldera complex (TMCC), $457 \mathrm{~m}$ (1,500 ft) north of generally west-draining Beatty Wash (Figure 4-1). This site is in the southern part of the nested Rainier Mesa and Ammonia Tanks calderas, both calderas of the TMCC. The formation of these calderas is the result of the eruption of the Rainier Mesa Tuff (erupted 11.6 million years ago [Ma] [Sawyer, et al., 1994]) and the Ammonia Tanks Tuff (erupted 11.45 Ma [Sawyer, et al., 1994]); both formations are part of the Timber Mountain Group. Following the collapse of the Ammonia Tanks caldera, resurgence of a central dome created the present topographic expression of the TMCC, including Timber Mountain and the surrounding "moat" (Figure 4-1). Younger volcanic rocks partially filled the moat, burying most of the Timber Mountain Group rocks within the moat. Moat-filling units exposed at the surface near Well ER-EC-7 (Figure 4-2) consist mainly of tuff and rhyolite lava of the Volcanics of Fortymile Canyon (erupted from various vents near the TMCC shortly after resurgence of the central dome of the Ammonia Tanks caldera) and younger moat-filling gravels and alluvium.

The location of Well ER-EC-7 was chosen, in part, to obtain subsurface data for the area south of a geophysically inferred, east-west striking, transverse fault (IT, 1998). The eastward extent of this structure, known as the Hot Springs fault (Grauch et al., 1997) is uncertain, (see Mankinen 
This page intentionally left blank. 


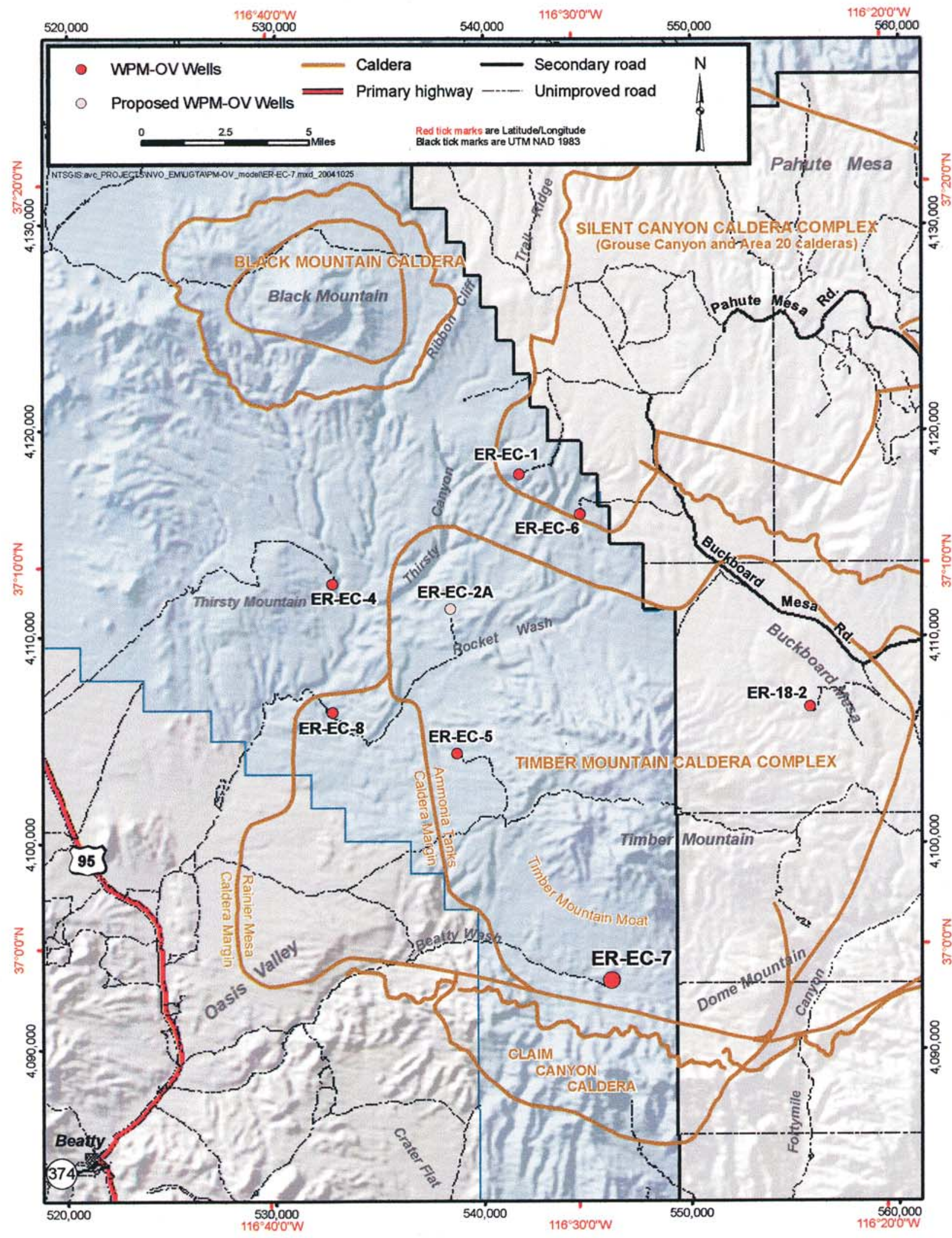

Figure 4-1

Map of Western Pahute Mesa - Oasis Valley Area Showing Theorized Locations of Caldera Boundaries (data from Wahl et al., 1997) 
This page intentionally left blank. 


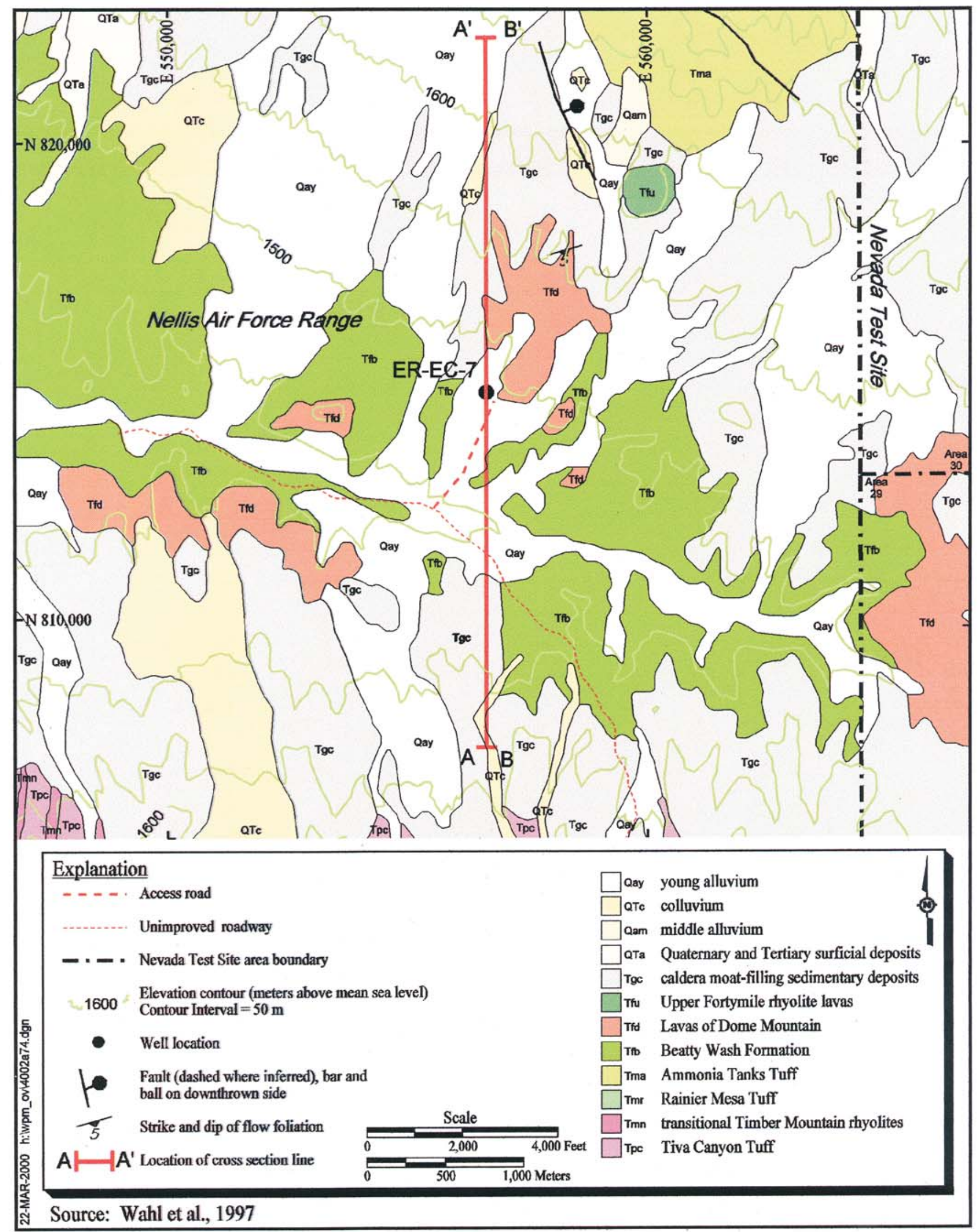

Figure 4-2

Surface Geologic Map of the Well ER-EC-7 Site 
This page intentionally left blank. 
et al., 1999, and Fridrich et al., 1999). However, whether this subsurface fault extends as far as the location of Well ER-EC-7 or not, the well does provide valuable information on the thickness, lithologic composition, and hydrogeologic character of moat-filling rocks in the southern portion of the TMCC.

The stratigraphy and lithology of Well ER-EC-7 are illustrated in Figure 4-3. Well ER-EC-7 first encountered a section of Quaternary alluvial debris $12.5 \mathrm{~m}(41 \mathrm{ft})$ deep at the well site. All units penetrated beneath the alluvium to TD are assigned to the Volcanics of Fortymile Canyon. Stratigraphic units within this group are identified where possible, as described in the following paragraphs. Hydrothermal alteration of the deeper rocks in Well ER-EC-7, as well as some degradation of data (cuttings and geophysical logs) quality due to borehole instability, make stratigraphic and lithologic assignments of units below the depth of $314.2 \mathrm{~m}$ (1,031 ft) difficult and less certain than for rocks in the upper part of the hole.

Well ER-EC-7 penetrated $301.8 \mathrm{~m}$ (990 ft) of rhyolitic lava, including intervals of pumiceous lava, vitrophyric lava, and flow breccia, assigned to the rhyolite of Beatty Wash, a subunit of the Beatty Wash Formation. The assignment of this interval to the rhyolite of Beatty Wash is based mainly on the presence of significant amounts of biotite and sphene, and the general absence of quartz. The sequence of lava-flow facies encountered within the rhyolite of Beatty Wash in Well ER-EC-7 match well with those described for surface exposures in the area (Byers et al., 1976). Below the rhyolite of Beatty Wash, the well penetrated $37.8 \mathrm{~m}$ (124 ft) of quartz-bearing bedded tuff overlying $17.1 \mathrm{~m}$ (56 ft) of quartz-bearing lava, both assigned to the rhyolite of Chukar Canyon, which is another subunit of the Beatty Wash Formation. This stratigraphic assignment is based on the presence of quartz and pseudomorphs after clinopyroxene, as well as additional information from detailed mineralogic and chemical analyses.

Below the quartz-bearing lava, the well encountered another interval of lava containing appreciable amounts of biotite and sphene, but no quartz. The upper portion of this interval above the depth of approximately $396.2 \mathrm{~m}(1,300 \mathrm{ft})$ is petrographically similar to the interval of lava assigned as rhyolite of Beatty Wash encountered higher in the well, and thus is likely another subunit of the Beatty Wash Formation. Detailed laboratory analyses of samples from below the depth of $396.2 \mathrm{~m}$ $(1,300 \mathrm{ft})$ suggest that the lower portion of the interval may be equivalent to tuff of Leadfield Road, 
This page intentionally left blank. 


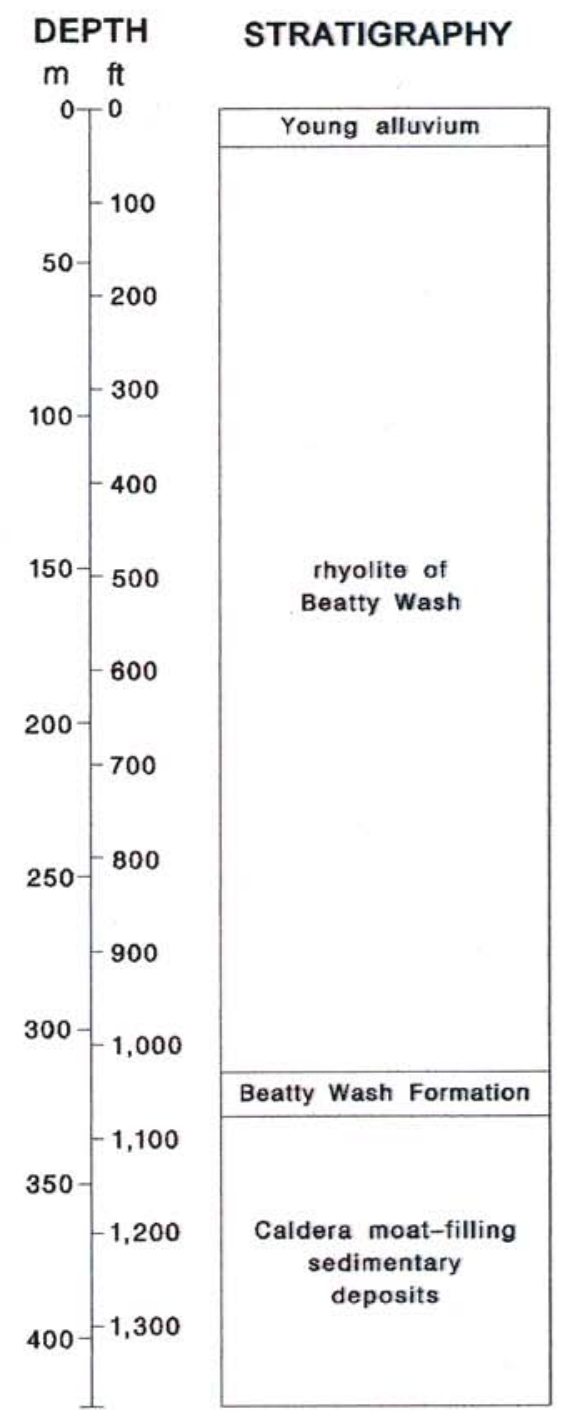

\section{LITHOLOGY}
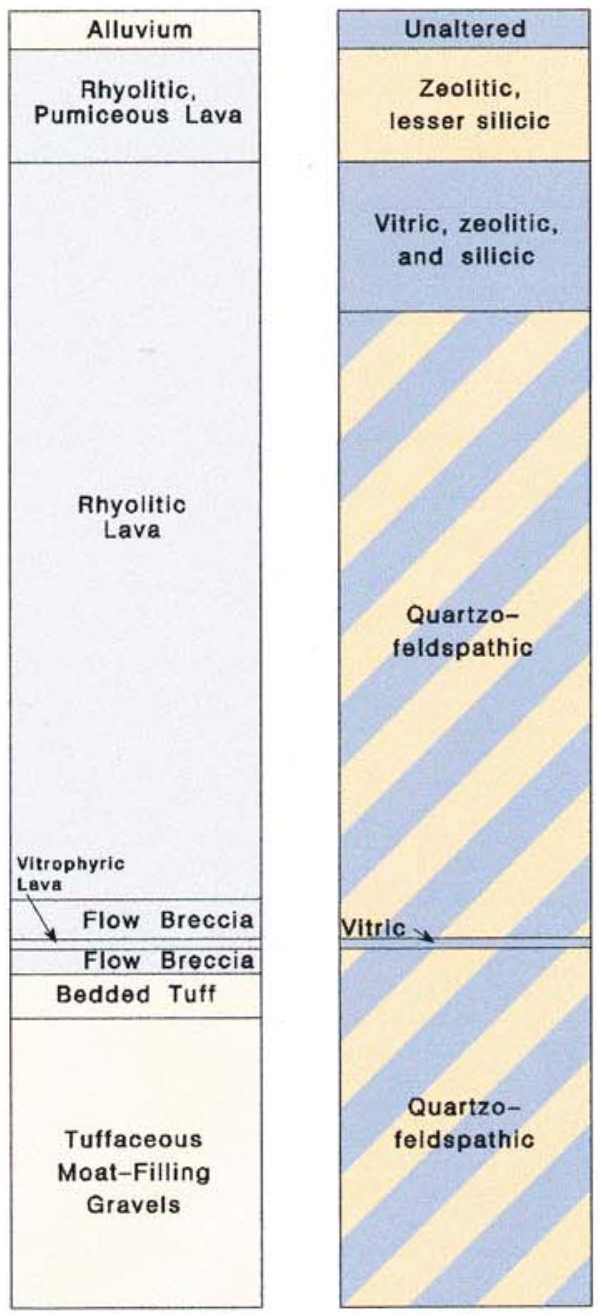

Vitric or

unaltered

Zeolitic

Alluvium, Tulfaceous Sediments, and
Bedded Tuff

\section{ALTERATION}

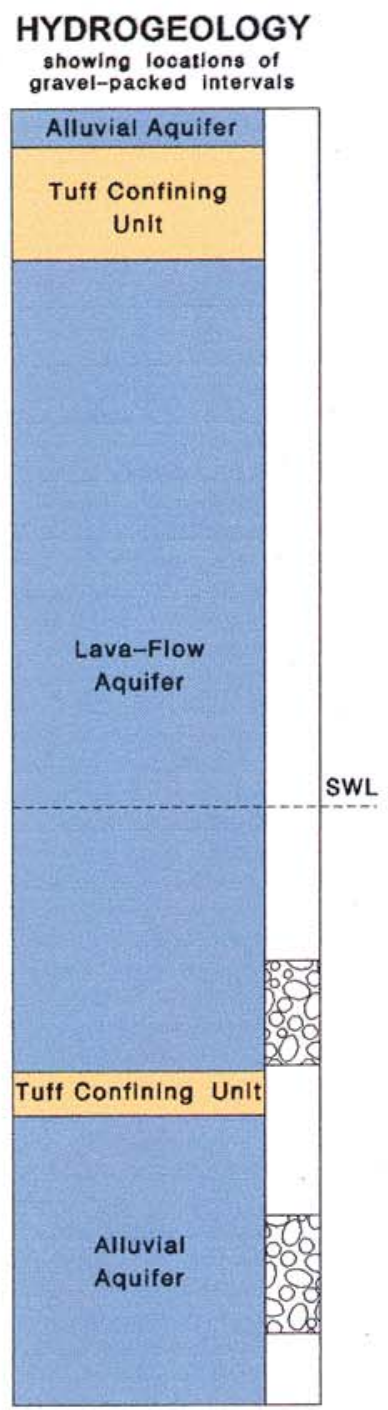

Quartzofeldspathic
Figure 4-3

Geology and Hydrogeology of Well ER-EC-7 
This page intentionally left blank. 
a formation within the Volcanics of Fortymile Canyon. Well ER-EC-7 reached TD in this lava after penetrating approximately $26.2 \mathrm{~m}(86 \mathrm{ft})$ of the unit.

The relative position, extent, and thickness of the stratigraphic units near Well ER-EC-7 are illustrated on the cross section in Figure 4-4. The figure shows Well ER-EC-7 within the structural margins of both the Rainier Mesa and Ammonia Tanks calderas. This interpretation is based on regional analyses of surface geology and gravity data (Warren et al., 2000; Drellack et al., 2000). Because Well ER-EC-7 was not drilled deep enough to reach the Timber Mountain tuffs, it does not provide any direct evidence as to the position of the structural margins (caldera-forming faults) of individual calderas in the area. However, the thick interval of Volcanics of Fortymile Canyon penetrated by the well is consistent with regional analyses that indicate the well lies within the topographic margin of the TMCC (Byers et al., 1976).

\subsubsection{Alteration}

Alteration has a significant effect on both the general hydraulic character of volcanic rocks and on how radionuclides migrate through these rocks. The predominant type of mineralogic alteration observed in each stratigraphic unit encountered in Well ER-EC-7 is illustrated on Figure 4-3.

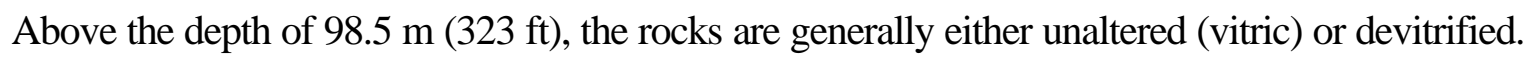

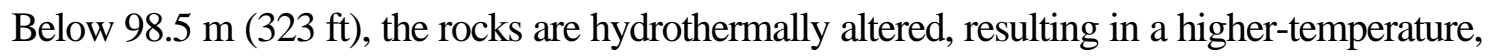
quartzo-feldspathic assemblage of alteration minerals. Alteration intensity generally increases with depth to approximately $369.1 \mathrm{~m}(1,211 \mathrm{ft})$, with the bedded tuffs of the rhyolite of Chukar Canyon

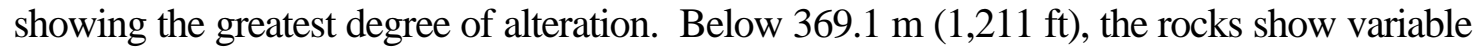
alteration, including zeolitization, devitrification, and higher temperature quartzo-feldspathic alteration.

\subsection{Predicted Versus Actual Geology}

The predicted geology for Well ER-EC-7 (IT, 1998) was based on geologic maps by Christiansen and Lipman (1965), Byers et al. (1976), and Wahl et al. (1997). A comparison of the predicted and the actual stratigraphy is provided in Figure 4-5. The well was predicted to penetrate a complete section of Volcanics of Fortymile Canyon and an interval of caldera moat-filling sediments before penetrating pre-Ammonia Tanks units (tuff of Crooked Canyon and tuff of Buttonhook Wash). The well was expected to reach TD in Ammonia Tanks Tuff at $762 \mathrm{~m}$ (2,500 ft), however,

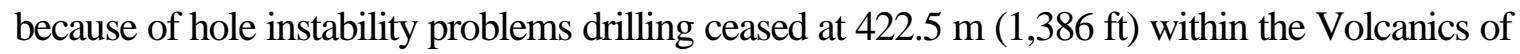
Fortymile Canyon. Pre-drilling predictions suggested that the bottom of the Volcanics of Fortymile 


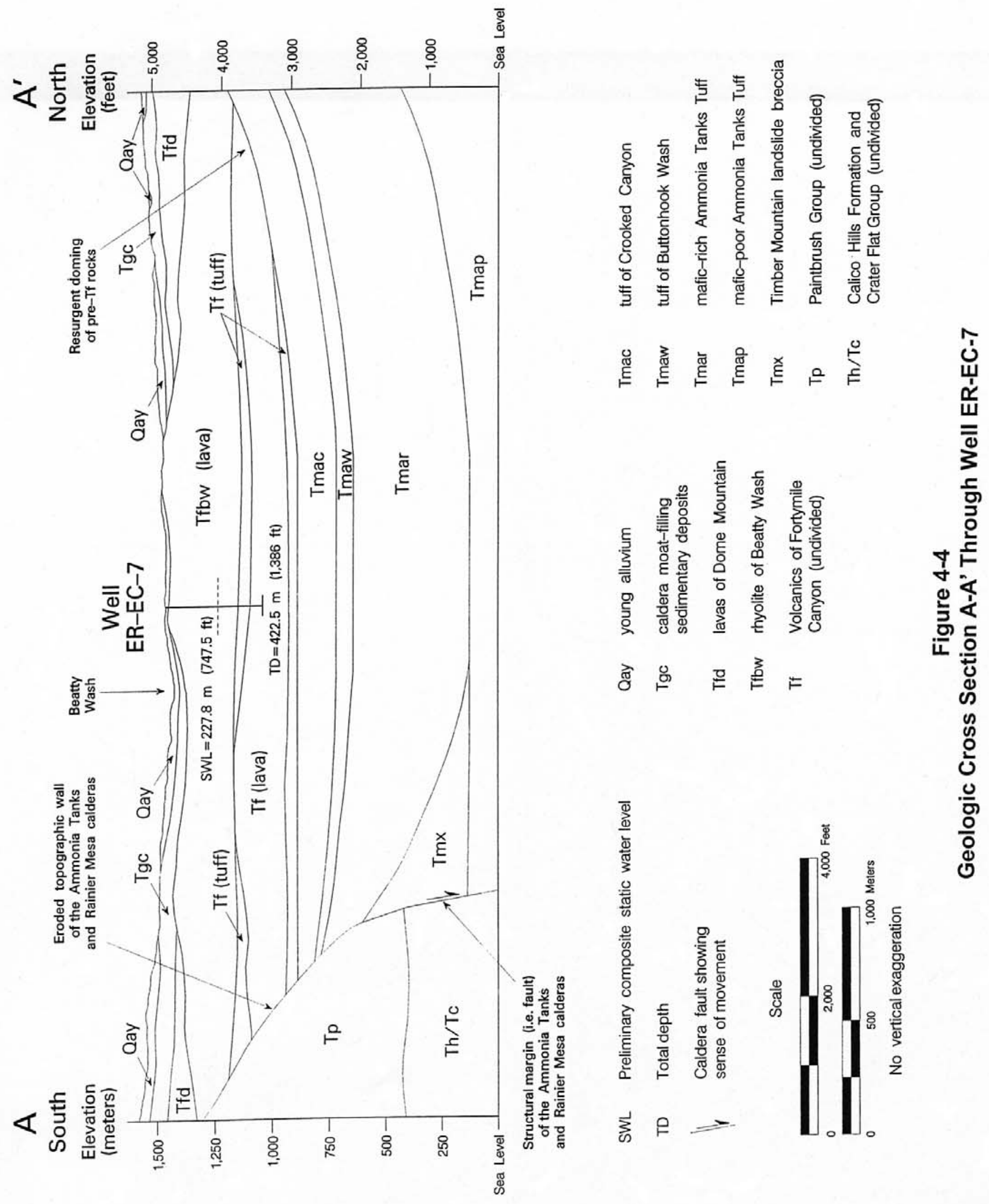




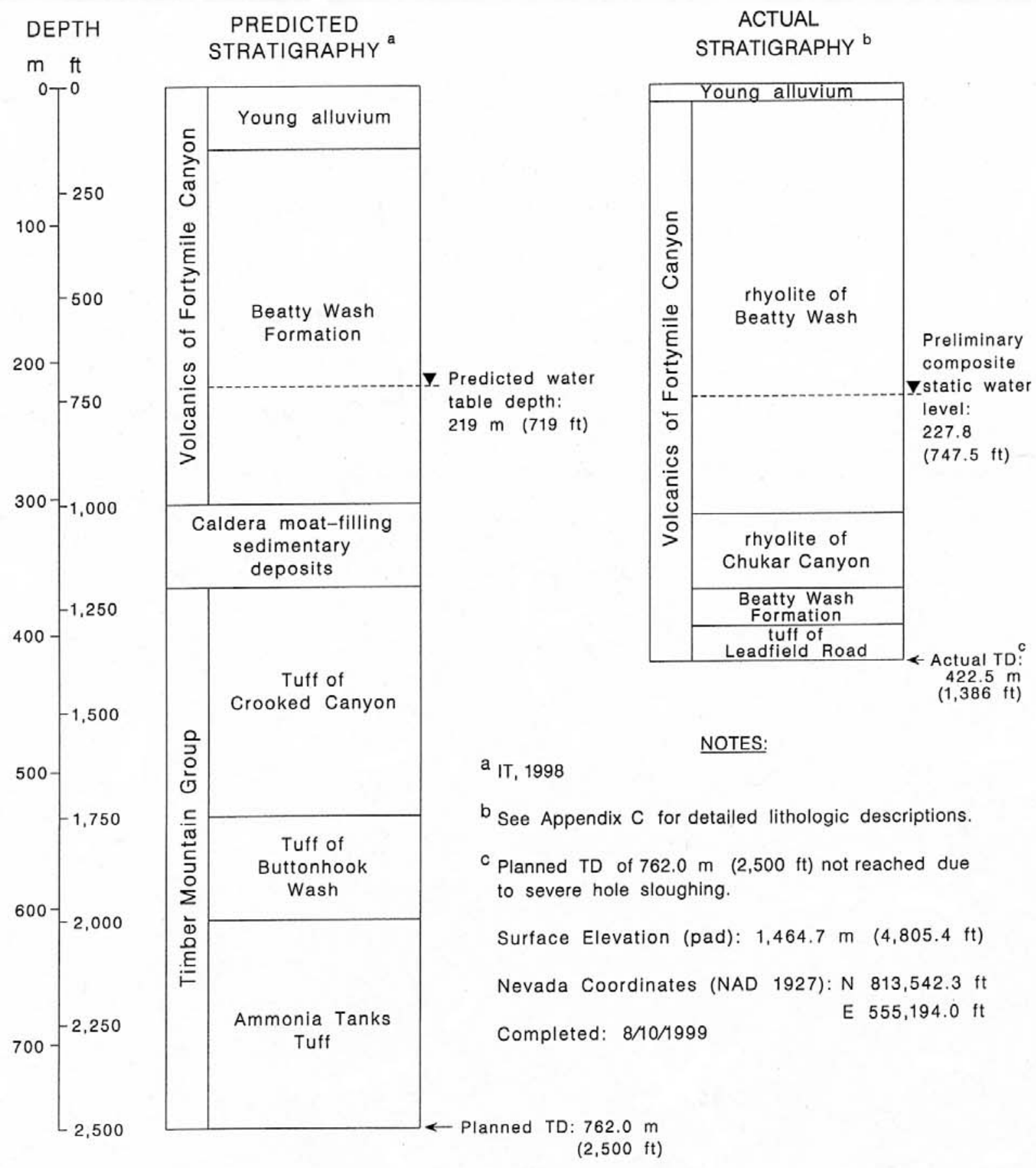

Figure 4-5

Predicted and Actual Stratigraphy at Well ER-EC-7

$4-13$ 
Canyon would be encountered at a depth of approximately $305 \mathrm{~m}(1,000 \mathrm{ft})$, thus the Volcanics of Fortymile Canyon are at least $117.7 \mathrm{~m}$ (386 ft) thicker than predicted prior to drilling.

\subsection{Hydrogeology}

The rocks of Well ER-EC-7 have been subdivided into hydrogeologic units, as illustrated in Figure 4-3. An interpretation of the distribution of these units is shown in cross section on Figure 4-6. Because of the limited and preliminary nature of data from the area around Well ER-EC-7, and the difficulty in predicting the lateral continuity of hydraulic properties of volcanic rocks, the cross section is rather conjectural. However, it does illustrate the complexities associated with the distribution of hydrogeologic units in caldera settings such as at Well ER-EC-7.

The dominant hydrogeologic unit in Well ER-EC-7 is lava-flow aquifer, consisting of mostly quartzo-feldspathic lava and flow breccia, and comprising approximately 80 percent of the rocks penetrated by the well. Because the lavas in the lower portion of the hole exhibit a wide range of alteration intensities, the hydraulic properties of these rocks may vary significantly. Below the water table, the only other hydrogeologic unit encountered in the borehole is a relatively thin interval (37.8 m [124 ft]) of tuff confining unit consisting of quartzo-feldspathic bedded tuff. This confining unit separates the upper lava-flow aquifer (lava and flow breccia of the rhyolite of Beatty Wash) from the lower interval of lava-flow aquifer.

See the discussion of the general hydraulic properties of the hydrogeologic units, including lava-flow aquifer, expected in Well ER-EC-7 in IT (1998), Section G.6.2 and Table G.6.1. Proposed hydrologic testing in the Well ER-EC-7 will verify the actual hydraulic character of the units encountered in the well. 

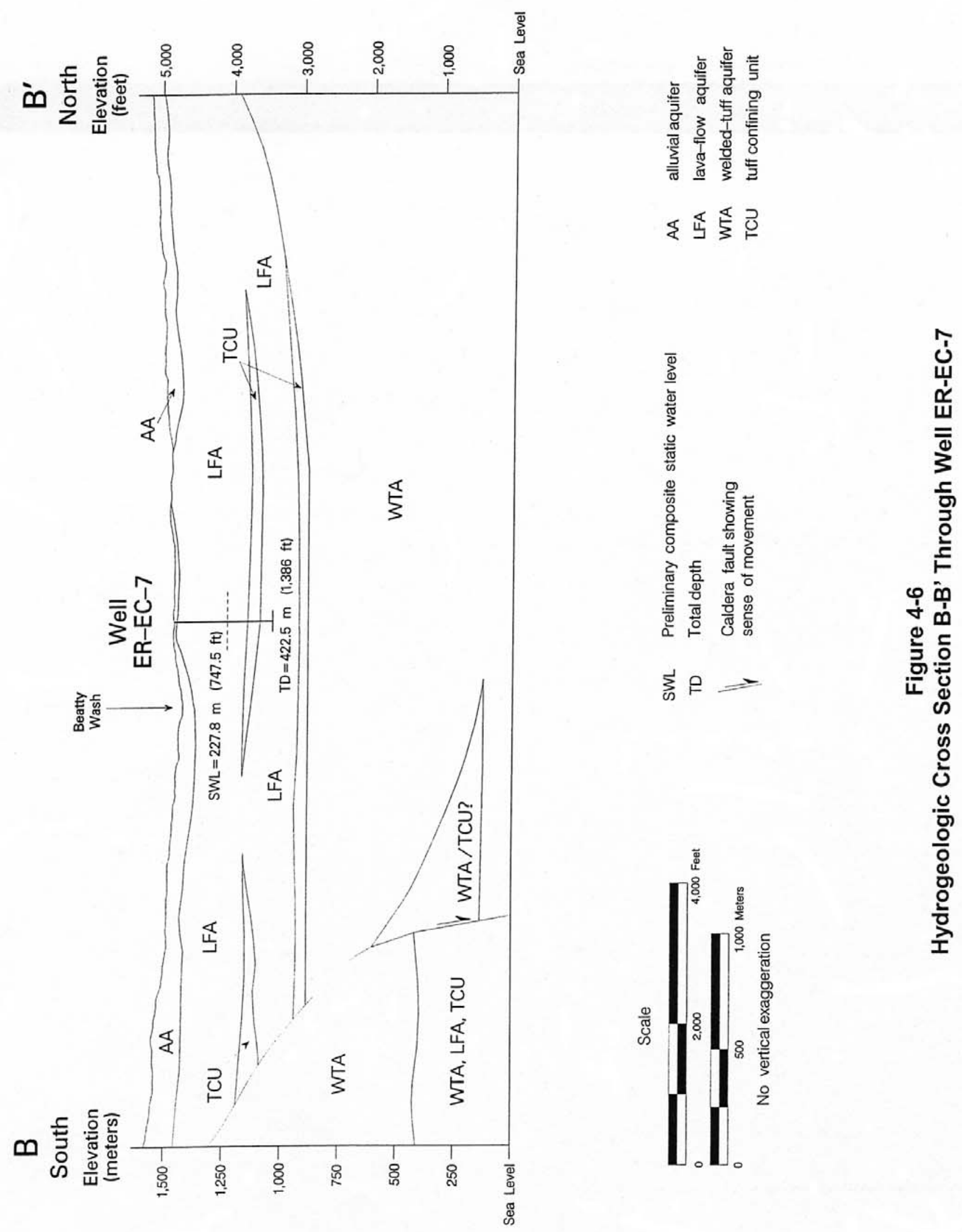
This page intentionally left blank. 


\subsection{Hydrology}

\subsection{Preliminary Water-Level Information}

The elevation of the water table at Well ER-EC-7 was projected to be approximately 1,244 m (4,081 ft), as derived from sparse hydrologic data for this region (IT, 1998). Based on the preconstruction estimate of surface elevation at the site, depth to water was expected at approximately $219 \mathrm{~m}$ (719 ft) (IT, 1998). During drilling, water production was first noted at a depth of $229.8 \mathrm{~m}$ $(754 \mathrm{ft})$ and the fluid level was tagged at the depth of $229.5 \mathrm{~m}(753 \mathrm{ft})$ before the $13 \mathrm{~d}$-in. surface casing was installed. A fluid depth of $228.0 \mathrm{~m}$ (748 ft) was obtained from the Desert Research Institute (DRI) Chemistry/Temperature log run on August 7, 1999, before the completion string was installed. Twenty days after the completion string was set, on August 30, 1999, IT measured the fluid level at the depth of $227.8 \mathrm{~m}$ (747.5 ft) (IT, 1999). Based on this composite fluid level depth and the surface elevation of $1,464.7 \mathrm{~m}(4,805.4 \mathrm{ft})$, the fluid level elevation at Well ER-EC-7 is $1,236.8 \mathrm{~m}(4,057.9 \mathrm{ft})$. This is approximately $7.1 \mathrm{~m}(23.3 \mathrm{ft})$ below the predicted elevation of $1,244 \mathrm{~m}(4,081 \mathrm{ft})$. A transducer for monitoring of the water level was not installed as part of the completion activities.

\subsection{Water Production}

Water production was estimated on the basis of $\mathrm{LiBr}$ dilution data as measured by IT field personnel. Measurable water production (approximately $18.9 \mathrm{lpm}$ [5 gpm]) began at the depth of approximately $229.8 \mathrm{~m}$ (754 ft) within lava of the Beatty Wash Formation. The production rate increased steadily but slowly, remaining at less than $378.5 \mathrm{lpm}$ (100 gpm) through the lower part of the Beatty Wash Formation and into the undivided, lower part of the Volcanics of Fortymile Canyon Group lavas. At a depth of about $356.6 \mathrm{~m}(1,170 \mathrm{ft})$, within one of the lower lavas, water production began to increase at a faster rate. Production increased from about $378.5 \mathrm{lpm}$ $(100 \mathrm{gpm})$ at $356.6 \mathrm{~m}(1,170 \mathrm{ft})$ to about 1,514 lpm (400 gpm) at $389.5 \mathrm{~m}(1,278 \mathrm{ft})$. At approximately $396.2 \mathrm{~m}$ (1,300 ft), water production increased suddenly from about 2,176 lpm (575 gpm) to about 3,028 lpm (800 gpm), and continued to increase steadily to a maximum of approximately $5,111 \mathrm{lpm}(1,350 \mathrm{gpm})$ near the TD of $422.5 \mathrm{~m}$ (1,386 ft). Estimated water production rates are presented graphically in Appendix A-1.

\subsection{Preliminary Thermal Flow Meter Data}

Thermal flow meter (TFM) data, along with temperature, electrical conductivity (EC), and $\mathrm{pH}$ measurements, can characterize borehole fluid variability, which may indicate inflow and outflow zones. The design of the completion string for Well ER-EC-7 was based in part on these data. 
Desert Research Institute personnel made TFM measurements at five locations between the depths of 257.6 and $397.8 \mathrm{~m}$ (845 and 1,305 ft) in Well ER-EC-7 before the completion string was installed. In addition, DRI ran a chemistry log, including temperature, $\mathrm{EC}$, and $\mathrm{pH}$, from 228.0 to $400.5 \mathrm{~m}$ (748 to $1,314 \mathrm{ft}$ ). The temperature of the borehole fluid varied only slightly from top to bottom, within a range of 2.5 degrees Celsius (C) (4.5 degrees Fahrenheit [F]). The maximum temperature in the borehole of 29.9 degrees $C$ ( 85.8 degrees F) was recorded at the depth of approximately $253 \mathrm{~m}(830 \mathrm{ft})$, near the bottom of the surface casing. This elevated temperature is believed to reflect the high curing temperature of the cement used to seal the annulus at bottom of the casing. The minimum temperature of 27.4 degrees $\mathrm{C}$ ( 81.3 degrees $\mathrm{F}$ ) was recorded at the depth of approximately $282 \mathrm{~m}(925 \mathrm{ft})$, and corresponds to a water-inflow location. Marked changes in the $\mathrm{pH}$ and $\mathrm{EC}$ of the borehole fluid were recorded at that same depth. Below $282 \mathrm{~m}$ $(925 \mathrm{ft})$, the temperature gradually increased to the second highest recorded temperature of 29.8 degrees $\mathrm{C}$ (85.6 degrees F) at the bottom of the borehole.

Preliminary analysis of a plot of the discrete TFM data points indicates a steady downward flow of water within the borehole between the depths of 280.7 and $397.8 \mathrm{~m}$ (921 and 1,305 ft). Plots of the TFM and chemistry log data are reproduced in Appendix D.

\subsection{Preliminary Groundwater Characterization Samples}

Following geophysical logging, DRI collected preliminary groundwater characterization samples at one location within the open borehole. Two samples were collected at the depth of $281.9 \mathrm{~m}$ (925 ft). Analytical data from these initial samples, collected before formal well development, will provide a basis for comparison with future groundwater chemistry data. 


\subsection{Precompletion and Open-Hole Development}

The only precompletion development conducted in Well ER-EC-7 consisted of circulating fluid for one hour to clean the borehole. This process was conducted while awaiting the decision to stop drilling, and prior to geophysical logging. 
This page intentionally left blank. 


\subsection{Well Completion}

\subsection{Introduction}

Well completion refers to the installation in a borehole of a string of pipe or casing that is slotted or screened at one or more locations along its length. The completion process also typically includes emplacement of backfill materials around the casing, with coarse fill such as gravel adjacent to the open intervals and impervious materials such as cement between the open intervals to isolate them. The casing serves as a conduit for insertion of a pump in the well, for inserting devices for measuring the fluid level, and for sampling, so that accurate potentiometric and water chemistry data can be obtained from a known portion of the borehole.

Completion activities at Well ER-EC-7 took place on August 9 and 10, 1999. Figure 7-1 is a schematic of the final well-completion design for Well ER-EC-7; Figure 7-2 shows a plan view and profile of the wellhead surface completion; and Table 7-1 is a construction summary for the well. Data for this section were obtained from daily operations and activity reports, casing records, and cementing records provided by the BN Drilling Department. Information from IT's well data report (IT, 1999) was also consulted for preparation of this section.

\subsection{Well Completion Design}

The final completion design differs slightly from the proposed design, as described in the following paragraphs.

\subsubsection{Proposed Completion Design}

The original completion design (IT, 1998) was based on the assumption that Well ER-EC-7 would penetrate a thick welded-tuff aquifer within the Tuff of Buttonhook wash and the Ammonia Tanks Tuff. The well was planned to be completed with a single casing string consisting of $51 / 2$-in. stainless steel casing, with every other joint slotted, suspended on carbon-steel 7e -in. casing. The primary goal was to obtain satisfactory completion within the welded-tuff aquifer, but the proposed completion design also called for the isolation (using non-slotted casing) of low transmissivity zones within the completion interval, if such zones could be identified. 


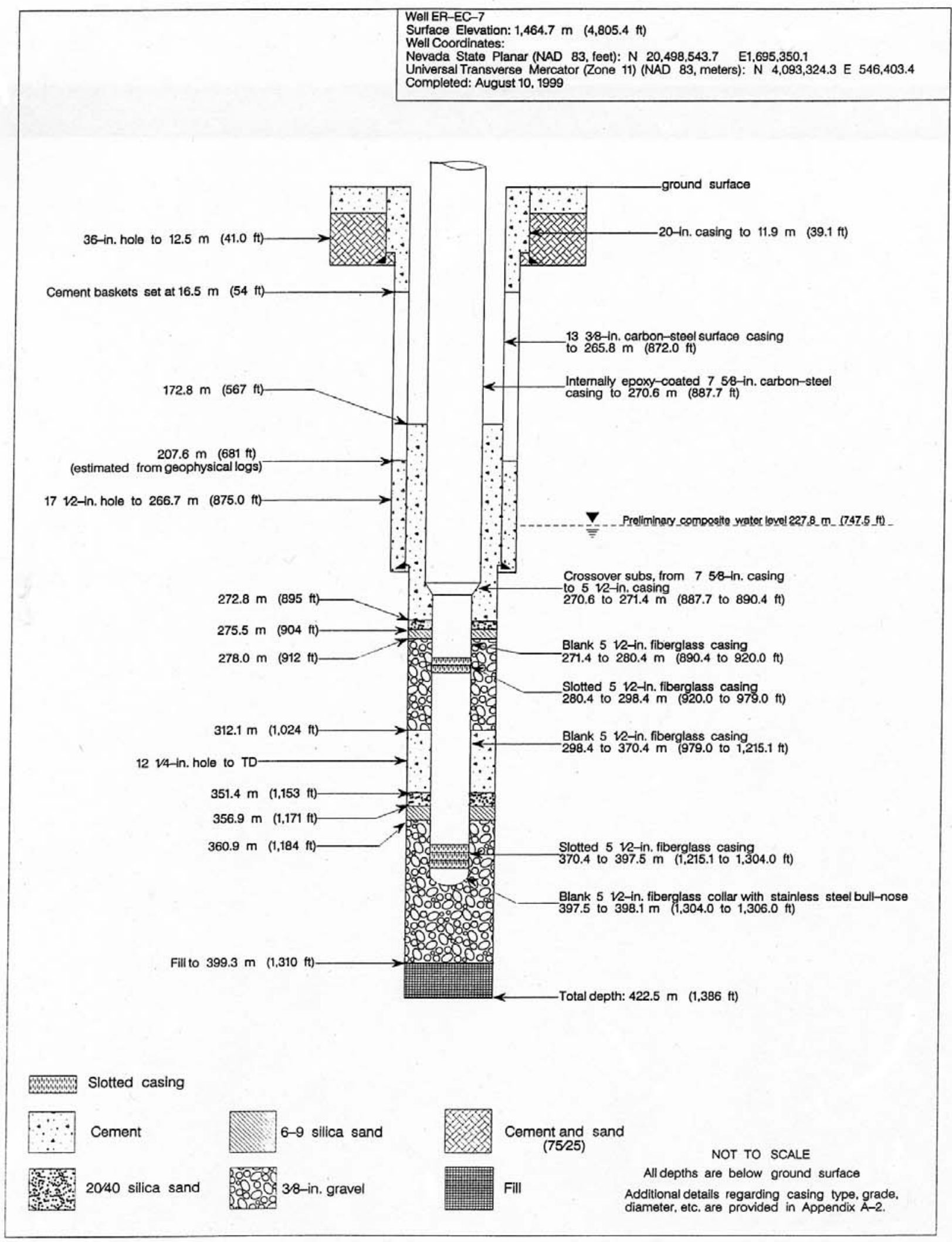

Figure 7-1

As-built Completion Schematic for Well ER-EC-7 


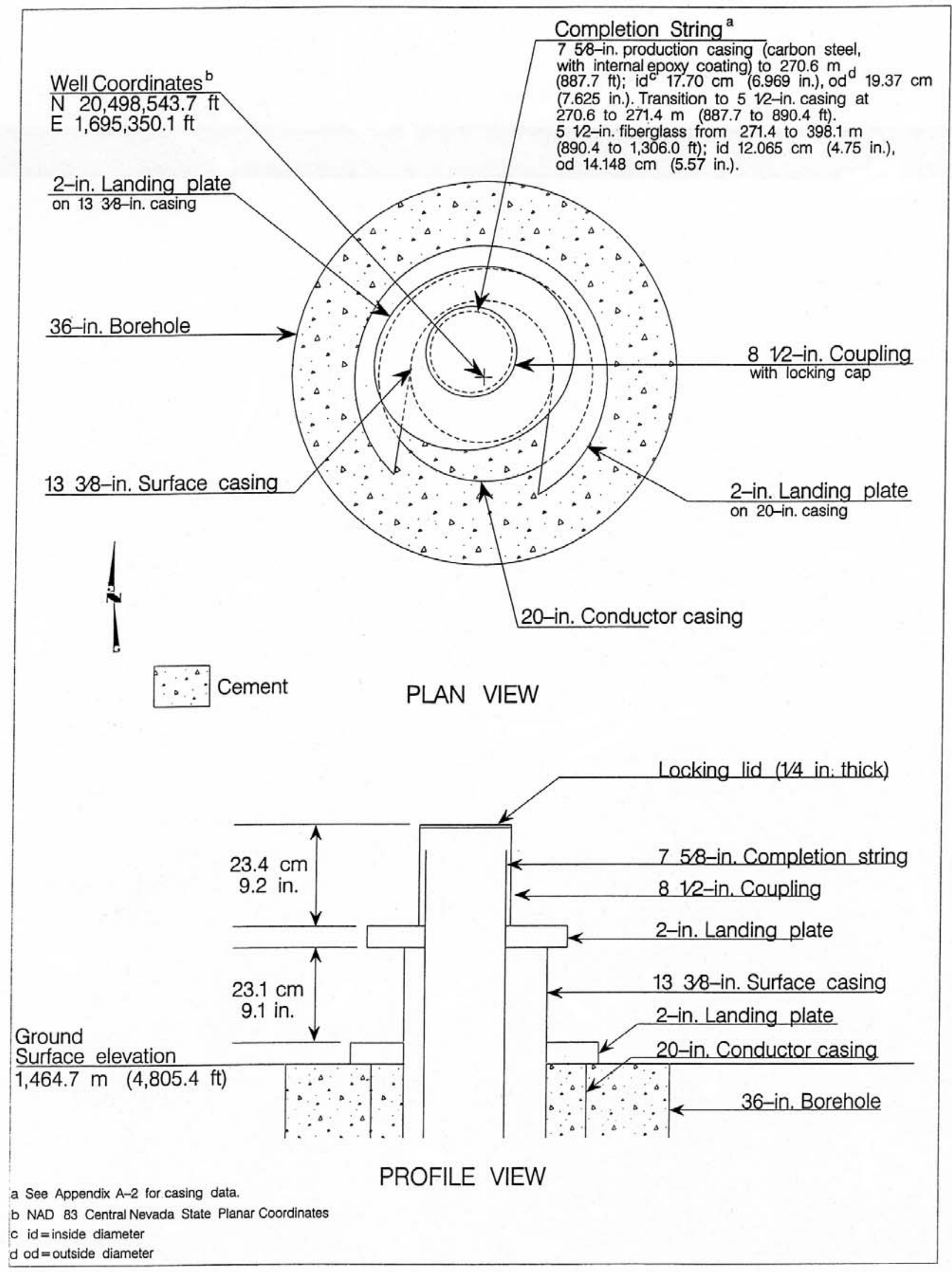

Figure 7-2

Wellhead Diagram for Well ER-EC-7 
Table 7-1

Well ER-EC-7 Completion String Construction Summary

\begin{tabular}{|c|c|c|c|c|}
\hline Casing Type & \multicolumn{2}{|c|}{$\begin{array}{c}\text { Configuration } \\
\text { meters (feet) }\end{array}$} & Cement & Sand/Gravel \\
\hline $\begin{array}{c}\text { 7e -in. carbon-steel } \\
\text { production casing } \\
\text { with internal epoxy } \\
\text { coating }\end{array}$ & $\begin{array}{l}0 \text { to } 270.6 \\
(0 \text { to } 887.7)\end{array}$ & Blank & \multirow{2}{*}{$\begin{array}{c}\text { Type II } \\
172.8 \text { to } 272.8 \\
\text { (567 to } 895 \text { ) }\end{array}$} & \multirow{2}{*}{ None } \\
\hline $\begin{array}{l}7 \text { e -in. to } 51 / 2 \text {-in. } \\
\text { crossover sub, } \\
\text { carbon-steel, with } \\
\text { fiberglass double pin }\end{array}$ & $\begin{array}{l}270.6 \text { to } 271.4 \\
(887.7 \text { to } 890.4)\end{array}$ & Blank & & \\
\hline \multirow{5}{*}{$\begin{array}{c}51 / 2 \text {-in. } \\
\text { fiberglass } \\
\text { production casing }\end{array}$} & \multirow{5}{*}{$\begin{array}{c}271.4 \text { to } 398.1 \\
(890.4 \text { to } 1,306.0)\end{array}$} & $\begin{array}{c}\text { Blank } \\
271.4 \text { to } 280.4 \\
\text { (890.4 to } 920.0)\end{array}$ & \multirow{5}{*}{$\begin{array}{c}\text { Type II } \\
312.1 \text { to } 351.4 \\
(1,024 \text { to } 1,153)\end{array}$} & $\begin{array}{c}\underline{20 / 40 \text { Sand }} \\
272.8 \text { to } 275.5 \\
\text { (895 to } 904)\end{array}$ \\
\hline & & $\begin{array}{l}2 \text { slotted joints } \\
280.4 \text { to } 298.4 \\
\text { (920.0 to } 979.0)\end{array}$ & & $\begin{array}{l}351.4 \text { to } 356.9 \\
(1,153 \text { to } 1,171)\end{array}$ \\
\hline & & $\begin{array}{c}\text { Blank } \\
298.4 \text { to } 370.4 \\
(979.0 \text { to } 1,215.1)\end{array}$ & & $\begin{array}{c}275.5 \text { to } 278.0 \\
\text { (904 to } 912 \text { ) } \\
356.9 \text { to } 360.9\end{array}$ \\
\hline & & $\begin{array}{c}3 \text { slotted joints } \\
370.4 \text { to } 397.5 \\
(1,215.1 \text { to } 1,304.0)\end{array}$ & & $\frac{3 / 8 \text {-in. } \times 4 \text { mesh }}{\text { Gravel }}$ \\
\hline & & $\begin{array}{c}\text { Blank and bull-nosed } \\
397.5 \text { to } 398.1 \\
(1,304.0 \text { to } 1,306.0)\end{array}$ & & $\begin{array}{c}278.0 \text { to } 312.1 \\
(912 \text { to } 1,024) \\
\\
360.9 \text { to } 399.3 \\
(1,184 \text { to } 1,310)\end{array}$ \\
\hline
\end{tabular}

\subsubsection{As-Built Completion Design}

The design of the Well ER-EC-7 completion was determined through consultation with members of the UGTA Technical Working Group, on the basis of on-site evaluation of data such as lithology and water production, drilling data (lost circulation, etc.), data from various geophysical logs, and from thermal-flow and water chemistry logs. The composition of the string summarized here is detailed on Table 7-1, and the casing materials are listed in Appendix A-2. 
The as-built completion design for Well ER-EC-7 (Figure 7-1) provides access to two lava-flow aquifers separated by a tuff confining unit. The lower section of the completion string, from 398.1 to $271.4 \mathrm{~m}(1,306.0$ to $890.4 \mathrm{ft})$, is $2000 \mathrm{DHC}$ fiberglass casing with an outside diameter of $14.15 \mathrm{~cm}$ (5.57 in.) and an inside diameter of $12.07 \mathrm{~cm}$ (4.75 in.). The top of the 51/2-in. casing is approximately $42.7 \mathrm{~m}$ (140 ft) below the static fluid level. The bottom 0.37-m (1.2-ft) long joint is a blank bull-nose which served as a guide shoe so that the string did not catch on ledges, etc., as it was inserted into the open hole. Above the fiberglass casing, a 0.82-m (2.7-ft) long crossover sub serves as the transition to the upper part of the string, which is $7 e$-in. carbon-steel production casing with an internal epoxy coating.

The lowest screened interval, 370.4 to $397.5 \mathrm{~m}$ (1,215.1 to 1,304.0 ft), is open to an altered lava of the Beatty Wash Formation. (See Figure 4-3 for an illustration of gravel-pack locations relative to hydrogeologic units.) This casing interval consists of two joints of slotted casing. The upper slotted interval, 280.4 to $298.4 \mathrm{~m}$ (920.0 to $979.0 \mathrm{ft}$ ) is open to lava and flow breccia within the rhyolite of Beatty Wash, and consists of two slotted joints.

The openings in each slotted casing joint are $0.198 \mathrm{~cm}(0.078 \mathrm{in}$.) wide and $5.1 \mathrm{~cm}$ (2 in.) long, cut in rings of 18 slots (spaced 20 degrees apart around the joint). The rings are spaced $15.2 \mathrm{~cm}(6 \mathrm{in}$.) apart, and the longitudinal centers of the slots in each ring are staggered 10 degrees from the slot centers in the next ring. No slots are cut within $0.6 \mathrm{~m}(2 \mathrm{ft})$ of the ends of the slotted joints to assure that the strength of the connections is not degraded. Each slotted joint has 900 slots.

\subsubsection{Rationale for Differences between Actual and Proposed Well Design}

Because Well ER-EC-7 was not drilled as deep as planned, the lava-flow aquifer unit in the Tuff of Buttonhook Wash and Ammonia Tanks Tuff was not encountered, and the planned completion zone in that unit was not constructed. Two separate lava-flow aquifers encountered in the Beatty Wash Formation and in the rhyolite of Beatty Wash were completed instead. The intervening tuff confining unit was isolated from the two open intervals by blank casing sections. However, the basic plan of installing a single string consisting of larger diameter carbon-steel casing above the water table and smaller diameter casing in the saturated zone was accomplished.

\subsection{Well Completion Method}

A "tremie" line and the completion string were landed after a brief period of circulation and conditioning of the hole. The two completion zones were gravel-packed and isolated from each other with sand and cement barriers. Caliper logs were used to calculate the volumes of stemming 
materials needed during well completion. Well-construction materials were inspected according to relevant procedures; standard decontamination procedures were employed to prevent the introduction of contaminants into the well.

The filter pack around each open interval consists of $0.95-\mathrm{cm}(\mathrm{d}-\mathrm{in}$.) by 4-mesh washed gravel, with 6-9 Colorado silica sand directly above the gravel, and 20/40 silica sand on top of the 6-9 sand. In this stemming design, developed by the UGTA program at the NTS, the layer of 20/40 sand serves as a barrier to any fluids that might seep from the cement above, preventing cement fluids from contaminating the groundwater (fluids from the cement would have the effect of drastically raising the $\mathrm{pH}$ of the groundwater). The underlying layer of 6-9 sand prevents the 20/40 sand from infiltrating the gravel-packed interval. All cement used in stemming the completion string was Type II Portland cement with no additives. A clear-water pre-flush and back-flush were made at each stage of cement emplacement. Gravel, sand, and cement were emplaced through the 2f -in. Hydril ${ }^{\circledR}$ tremie line that was withdrawn as the completion process progressed. A Nuclear Annulus Investigation Log was used to monitor the emplacement of stemming materials. As-built positions of the well materials are shown on Figure 7-1 and listed in Table 7-1.

Stemming of the hole began with the first stage of gravel emplaced from 399.3 to $360.9 \mathrm{~m}(1,310$ to $1,184 \mathrm{ft}$ ) on top of $23.2 \mathrm{~m}$ (76 ft) of fill at the bottom of the hole, and adjacent to the lowest slotted interval. This gravel pack is topped by a sand barrier to the depth of $351.4 \mathrm{~m}(1,153 \mathrm{ft})$, followed by cement, poured in two stages up to $312.1 \mathrm{~m}(1,024 \mathrm{ft})$. A second layer of gravel was placed between the depths of 312.1 and $278.0 \mathrm{~m}$ (1,024 and $912 \mathrm{ft}$ ), adjacent to the upper slotted interval; this gravel was topped with sand to the depth of $272.8 \mathrm{~m}$ (895 ft). The final cemented section extends to the depth of $172.8 \mathrm{~m}(567 \mathrm{ft})$.

The drill rig was released after cementing was completed. Hydrologic testing was planned as a separate effort, so a pump was not installed in the well, and no well-development or pumping tests were conducted immediately after completion. 


\subsection{Actual versus Planned Costs and Scheduling}

The BN cost model developed for Well ER-EC-7 was based on drilling to the planned TD of $762.0 \mathrm{~m}(2,500 \mathrm{ft})$. The drilling program baseline projected that it would require 17 days to accomplish drilling of the surface and main holes, logging, and completion for the well, assuming the conductor hole would already have been constructed by BN. The actual time spent to drill the main and surface holes, and install the completion string in Well ER-EC-7 was 11 days. A graphical comparison, by day, of planned and actual well-construction activities is presented in Figure 8-1.

The cost analysis for Well ER-EC-7 begins with drilling of the surface hole, after construction of the conductor hole. The total construction cost for Well ER-EC-7 includes all drilling costs: charges by the drilling subcontractor; charges by other support subcontractors (including compressor services, drilling fluids, bits, casing services, down-hole tools and, and geophysical logging); and charges by $\mathrm{BN}$ for mobilization and demobilization of equipment, cementing services, completion materials, radiation technicians, inspection services, and geotechnical consultation. The cost of building roads, the drill pad, and sumps is not included, and the cost of well-site support by IT is not included.

The total planned cost for construction Well ER-EC-7 was $\$ 1,180,477$. The actual cost was $\$ 731,869$, or 38.0 percent less than the planned cost. This reflects the fact that the well was not drilled as deep as planned, and required shorter completion strings. Figure 8-2 presents a comparison of the planned (baseline task plan) and actual costs, by day, for drilling and completing Well ER-EC-7. 


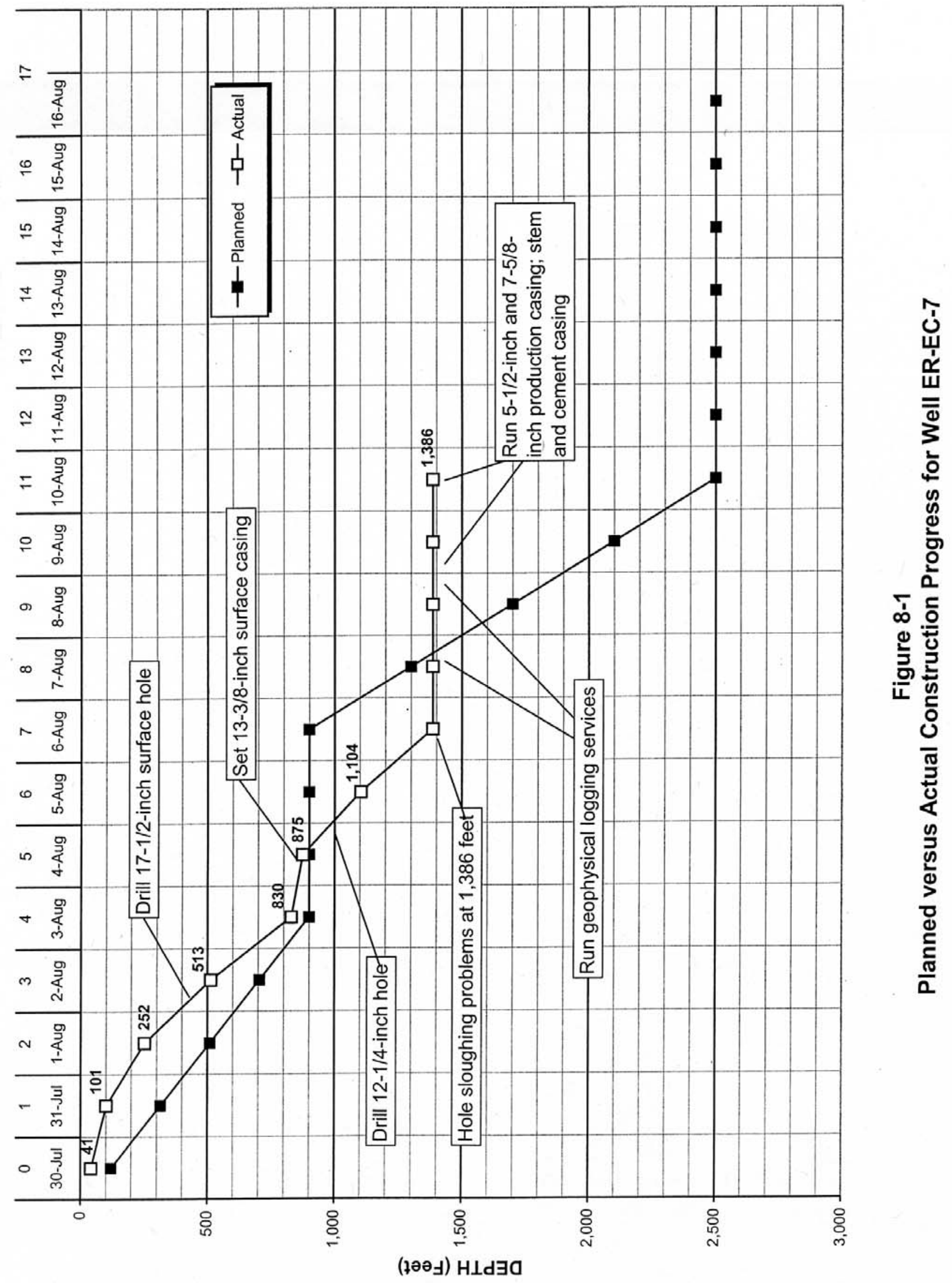




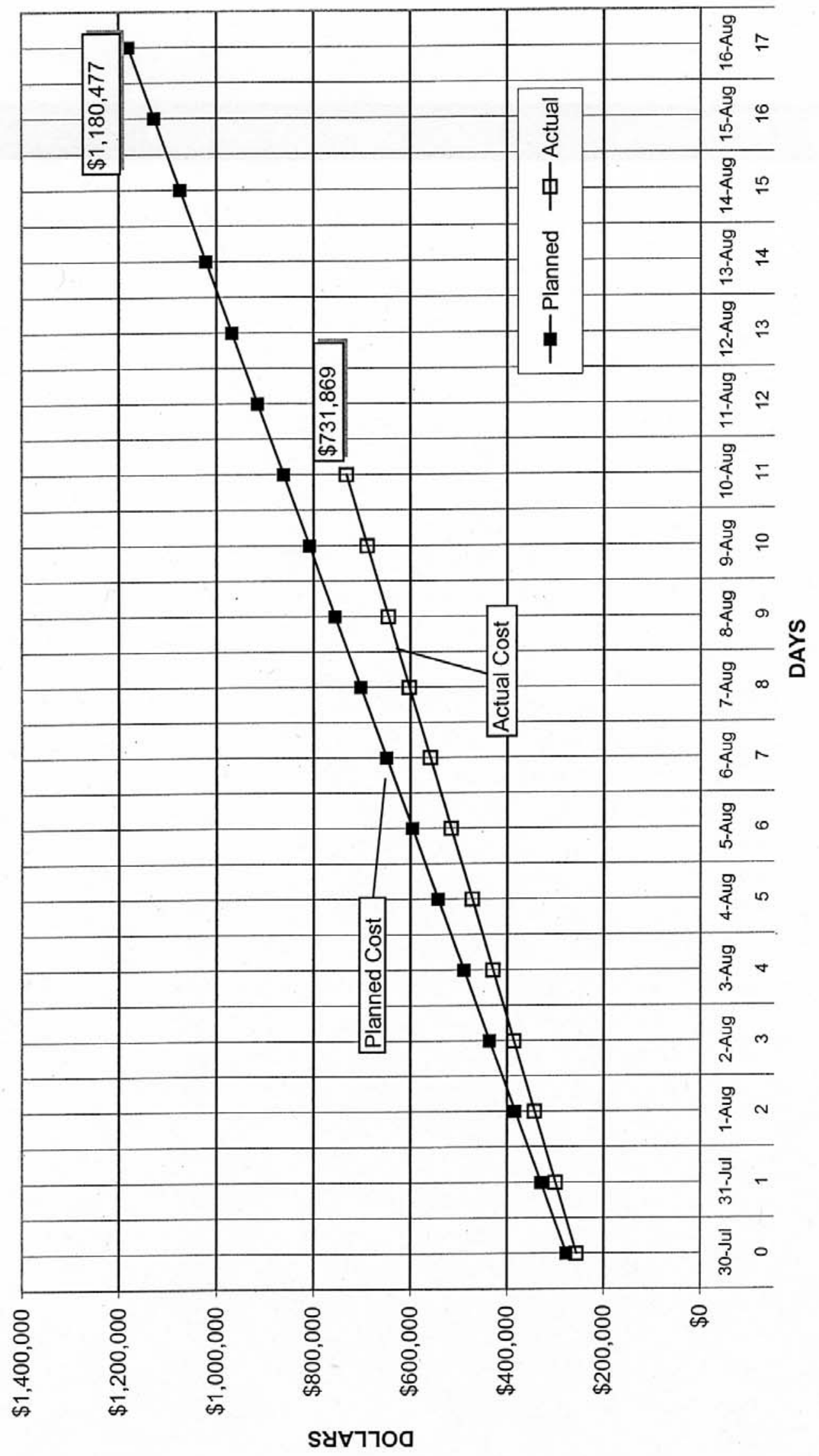

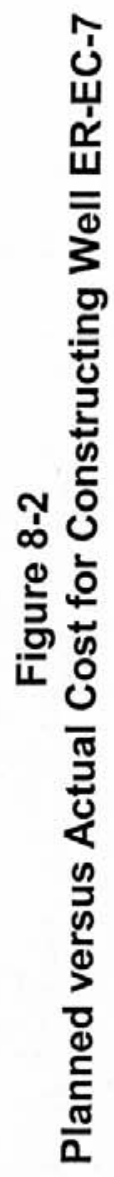


This page intentionally left blank. 


\subsection{Summary, Recommendations, and Lessons Learned}

\subsection{Summary}

Drilling subcontractor activities at Well ER-EC-7 commenced on July 30, 1999, and concluded on August 6, 1999, when the TD of $422.5 \mathrm{~m}$ (1,386 ft) was reached. After geophysical logging, the completion string was installed and gravel-packed, and the hole was stemmed to the depth of $172.8 \mathrm{~m}$ (567 ft) on August 9 and 10, 1999. Crews worked on a 7-days-per-week, 24-hours-perday schedule for most of the operation. Eleven working days were expended to drill the surface and main holes, conduct geophysical logging, and install the completion string. The only problem encountered during construction of Well ER-EC-7 was excessive borehole sloughing, which forced termination of drilling $339.5 \mathrm{~m}(1,114 \mathrm{ft})$ shallower than the planned TD of $762.0 \mathrm{~m}(2,500 \mathrm{ft})$.

No radionuclides above background were encountered in the groundwater produced from Well ER-EC-7. Preliminary (field-monitoring) and laboratory testing data indicated no lead or other hazardous materials above permitted levels in the drilling effluent.

Composite drill cuttings were collected every $3 \mathrm{~m}$ (10 ft) from $12.2 \mathrm{~m}$ (40 ft) to TD. No sidewall core samples were collected in Well ER-EC-7. Geophysical logging was not conducted in the upper part of the hole before installation of the surface casing, but was conducted in the lower part of the hole before installation of the completion string. Some of these logs were used to aid in construction of the well, while others help to verify the geology and determine the hydrologic characteristics of the rocks.

A single completion string with two gravel-packed, slotted intervals, was installed in Well ER-EC-7. A string of 51/2-in. fiberglass casing installed below the water table is suspended from $7 e$-in. carbon-steel casing (with an internal epoxy coating) which extends to the surface. The two open intervals in the 51/2-in. casing are centered within the gravel-pack intervals that are located at 278.0 to $312.1 \mathrm{~m}$ (912 to $1,024 \mathrm{ft}$ ) and 360.9 to $399.3 \mathrm{~m}$ (1,184 to $1,310 \mathrm{ft}$ ). These intervals are open to two lava-flow aquifers separated by a tuff confining unit, all part of the Volcanics of Fortymile Canyon.

IT personnel obtained a fluid depth of $227.8 \mathrm{~m}$ (747.5 ft) on August 30, 1999, 20 days after the completion string was installed (IT, 1999). 


\subsection{Recommendations}

The planned pump installation, well development, groundwater sampling, and hydrologic testing must be conducted at Well ER-EC-7 to accomplish the remaining objectives for this well-construction effort.

\subsection{Lessons Learned}

No new lessons were learned during the construction of Well ER-EC-7. However, a basic principal for data collection through exploratory drilling was re-experienced. There are sometimes trade-offs which must be made between construction methods, cost, and data collection. When there are hole problems, such as the sloughing experience at Well ER-EC-7, the cost and difficulties of continuing to obtain additional data must be weighed against the value of the data. In this case it was decided that the added costs associated with continuing the hole would have been too high compared to the programmatic benefit from any additional data collected. 


\subsection{References}

Bechtel Nevada, 1999a. Western Pahute Mesa/Oasis Valley (WPM-OV) Investigation Wells Site-Specific Health and Safety Plan (SSHASP). February 1999. Las Vegas, NV.

Bechtel Nevada, 1999b. Drilling Program for Underground Test Area (UGTA) Western Pahute Mesa/Oasis Valley (WPM-OV) Investigation Well ER-EC-7 - Original. Drilling Work Plan Number D-005-002.99. May 25, 1999. Las Vegas, NV.

Bechtel Nevada, 2002. A Hydrostratigraphic Model and Alternatives for the Groundwater Flow and Contaminant Transport Model of Corrective Action Units 101 and 102: Central and Western Pahute Mesa, Nye County, Nevada. DOE/NV/11718--706. Las Vegas, NV.

BN, see Bechtel Nevada.

Byers, F. M., Jr., W. J. Carr, R. L. Christiansen, P. W. Lipman, P. P. Orkild, and W. D. Quinlivan, 1976. "Geologic Map of the Timber Mountain Caldera Area, Nye County, Nevada." U.S. Geological Survey Miscellaneous Investigations Map I-891, scale, 1:48,000. Reston, VA.

Christiansen, R. L., and P. W. Lipman, 1965. "Geologic Quadrangle Map: Topopah Spring NW Quadrangle, Nevada.” U.S. Geological Survey Map GQ-444, scale, 1:24,000. Washington, D.C.

DOE, see U.S. Department of Energy.

Drellack, S.L., L. B. Prothro, J. L. Gonzales, and H. M. Noto, 2000. Written communication to P. K. Ortego, Bechtel Nevada, Las Vegas. Subject: "Transmittal of Geologic Interpretive Products for the Western Pahute Mesa - Oasis Valley Area to the U.S. Geological Survey." BN Memorandum Number 2152-MT-00-0014. May 3.

Ferguson, J. F., A. H. Cogbill, and R. G. Warren, 1994. "A Geophysical-Geologic Transect of the Silent Canyon Caldera Complex, Pahute Mesa, Nevada." In Journal of Geophysical Research, v. 99, n. 33, pp. 4,323-4,339.

Fridrich, C. D., S. A. Minor, and E. A. Mankinen, 1999. Geologic Evaluation of the Oasis Valley Basin, Nye County, Nevada, U.S. Geological Survey Open-File Report 99-533-A. Denver, $\mathrm{CO}$.

Grauch, V. J. S., D. A. Sawyer, C. J. Fridrich, and M. R. Hudson, 1997. Geophysical Interpretations West of and Within the Northwestern Part of the Nevada Test Site, U.S. Geological Survey Open-File Report 97-476. Denver, CO. 
Hildenbrand, T. G., V. E. Langenheim, E. A. Mankinen, and E. H. McKee, 1999. Inversion of Gravity Data to Define the Pre-Tertiary Surface and Regional Structures Possibly Influencing Ground-Water Flow in the Pahute Mesa - Oasis Valley Region, Nye County, Nevada, U.S. Geological Survey Open-File Report 99-49. Menlo Park, CA.

IT, see IT Corporation.

IT Corporation, 1998. FY99 Western Pahute Mesa - Oasis Valley Hydrogeologic Investigation Wells Drilling and Completion Criteria, ITLV/13052-049. Las Vegas, NV.

IT Corporation, 1999. Written communication prepared for DOE/NV. Subject: "Western Pahute Mesa - Oasis Valley ER-EC-7 Well Data Report,” ITLV/13052--080. Las Vegas, NV.

Mankinen, E. A., T. G. Hildenbrand, G. L. Dixon, E. H. McKee, C. J. Fridrich, and R. J. Laczniak, 1999. Gravity and Magnetic Study of the Pahute Mesa and Oasis Valley Region, Nye County, Nevada, U.S. Geological Survey Open-File Report 99-303. Menlo Park, CA.

Sawyer, D. A., J. J. Fleck, M. A. Lanphere, R. G. Warren, and D. E. Broxton, 1994. "Episodic Caldera Volcanism in the Miocene Southwest Nevada Volcanic Field: Revised Stratigraphic Caldera Framework, ${ }^{40} \mathrm{Ar} /{ }^{39} \mathrm{Ar}$ Geochronology, and Implications for Magmatism and Extension," Geological Society of America Bulletin, v. 67, n. 10, pp. 1,304-1,318.

U.S. Department of Energy, 1996a. Attachment 1, "Fluid Management Plan for the Underground Test Area Subproject." In Underground Test Area Subproject Waste Management Plan, Revision 1, DOE/NV--343. Las Vegas, NV.

U.S. Department of Energy, 1996b. Underground Test Area Subproject Waste Management Plan, Rev. 1, DOE/NV--343. Las Vegas, NV.

U.S. Department of Energy, 1998. Nevada Environmental Restoration Project Health and Safety Plan, Revision 3, February 1998. Las Vegas, NV.

Wahl, R. R., D. A. Sawyer, M. D. Carr, S. A. Minor, J. C. Cole, WC Swadley, R. J. Laczniak, R. G. Warren, K. S. Green, and C. M. Engle, 1997. "Digital Geologic Map of the Nevada Test Site Area, Nevada.” U.S. Geological Survey Open-File Report 97-140, scale, 1:120,000. Denver, CO.

Warren, R. G., 2000. Written communication to Lance Prothro, Bechtel Nevada, Las Vegas. Subject: "Interim Report for ER/EC7." May 24.

Warren, R. G., G. L. Cole, and D. Walther, 2000. A Structural Block Model for the ThreeDimensional Geology of the Southwestern Nevada Volcanic Field. Los Alamos National Laboratory Report LA-UR-00-5866. 


\section{Appendix A Drilling Data}

A-1 Drilling Parameter Log for Well ER-EC-7

A-2 Casing Data for Well ER-EC-7

A-3 Well ER-EC-7 Drilling Fluids and Cement Composition 
Appendix A-1

Drilling Parameter Log for Well ER-EC-7 


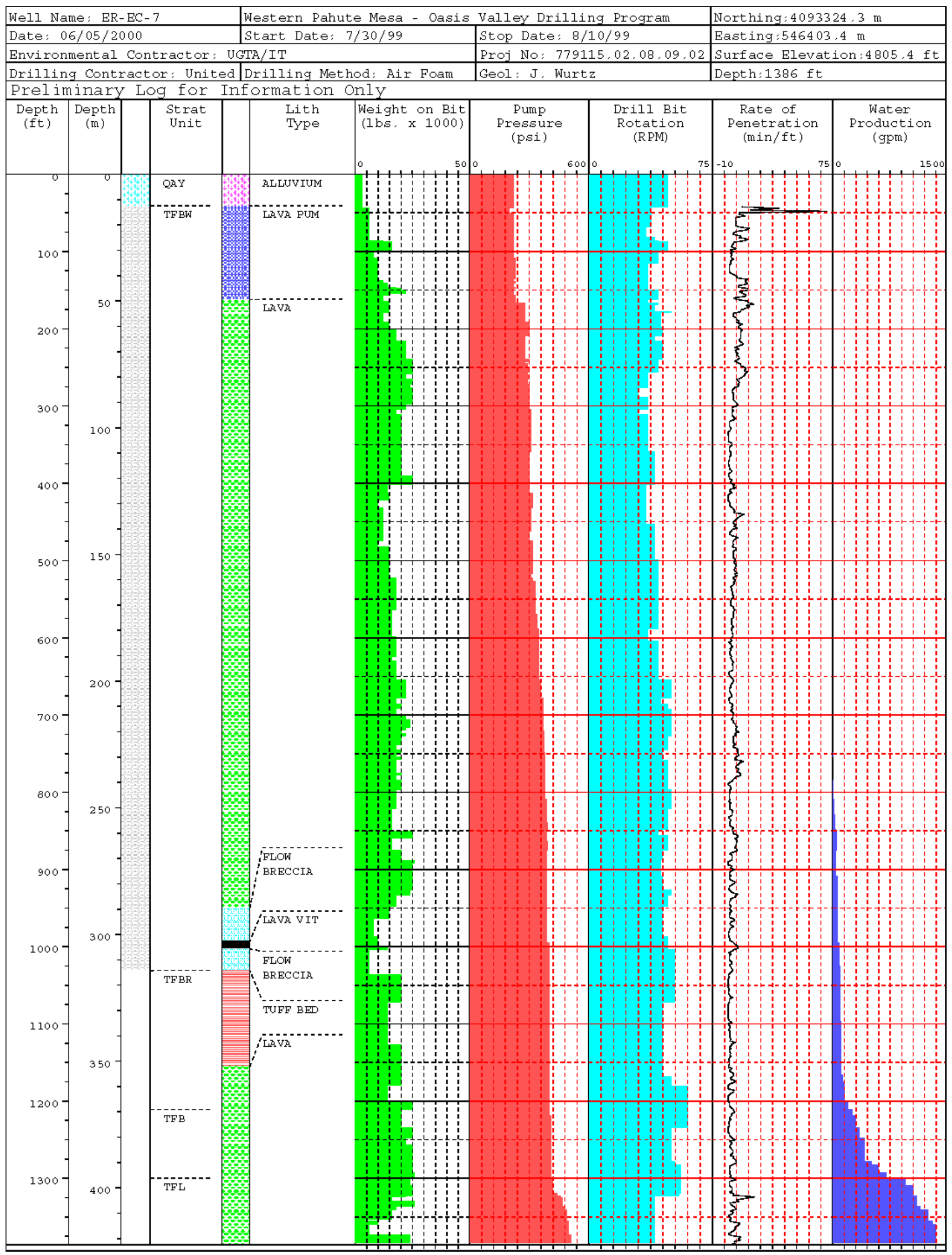


This page intentionally left blank.

A-1-2 
Appendix A-2

Casing Data for Well ER-EC-7 


\section{Casing Data for Well ER-EC-7}

\begin{tabular}{||c|c|c|c|c|c|c|c||}
\hline Casing & $\begin{array}{c}\text { Depth Interval } \\
\text { meters } \\
\text { (feet) }\end{array}$ & Type & Grade & $\begin{array}{c}\text { Outside } \\
\text { Diameter } \\
\text { centimeters } \\
\text { (inches) }\end{array}$ & $\begin{array}{c}\text { Inside } \\
\text { Diameter } \\
\text { centimeters } \\
\text { (inches) }\end{array}$ & $\begin{array}{c}\text { Wall } \\
\text { Thickness } \\
\text { centimeters } \\
\text { (inches) }\end{array}$ & $\begin{array}{c}\text { Weight } \\
\text { per foot } \\
\text { (pounds) }\end{array}$ \\
\hline $\begin{array}{c}\text { 20-inch Conductor } \\
\text { Casing }\end{array}$ & $\begin{array}{c}0 \text { to } 11.9 \\
\text { (0 to } 39.1)\end{array}$ & $\begin{array}{c}\text { Carbon } \\
\text { Steel }\end{array}$ & $\mathrm{K} 55$ & $\begin{array}{c}50.80 \\
(20)\end{array}$ & $\begin{array}{c}48.575 \\
19.124\end{array}$ & $\begin{array}{c}1.113 \\
(0.438)\end{array}$ & 94 \\
\hline $\begin{array}{c}\text { 13d -inch Surface } \\
\text { Casing }\end{array}$ & $\begin{array}{c}0 \text { to } 265.8 \\
\text { (0 to } 872.0)\end{array}$ & $\begin{array}{c}\text { Carbon } \\
\text { Steel }\end{array}$ & $\mathrm{K} 5$ & $\begin{array}{c}33.97 \\
(13.375)\end{array}$ & $\begin{array}{c}32.042 \\
(12.615)\end{array}$ & $\begin{array}{c}0.965 \\
(0.380)\end{array}$ & 54.5 \\
\hline $\begin{array}{c}\text { 7e-inch } \\
\text { Completion } \\
\text { Casing } \\
\text { (with crossover) }\end{array}$ & $\begin{array}{c}0 \text { to } 271.4 \\
(0 \text { to } 890.4)\end{array}$ & $\begin{array}{c}\text { Carbon } \\
\text { Steel with } \\
\text { internal } \\
\text { epoxy }\end{array}$ & $\mathrm{N} 80$ & $\begin{array}{c}19.37 \\
(7.625)\end{array}$ & $\begin{array}{c}17.701 \\
(6.969)\end{array}$ & $\begin{array}{c}0.833 \\
(0.328)\end{array}$ & 26.4 \\
\hline $\begin{array}{c}51 / 2 \text {-inch } \\
\text { completion } \\
\text { Casing }\end{array}$ & $\begin{array}{c}271.4 \text { to } 398.1 \\
(890.4 \text { to } 1,306.0)\end{array}$ & Fiberglass & $\begin{array}{c}2000 \\
\mathrm{DHC}\end{array}$ & $\begin{array}{c}14.15 \\
(5.57)\end{array}$ & $\begin{array}{c}12.065 \\
(4.750)\end{array}$ & $\begin{array}{c}1.041 \\
(0.410)\end{array}$ & 5.91 \\
\hline
\end{tabular}


This page intentionally left blank.

A-2-2 


\section{Appendix A-3}

Well ER-EC-7 Drilling Fluids and Cement Composition 
Table A-3-1

Well ER-EC-7 Drilling Fluids

\begin{tabular}{c}
\hline Typical Air-Foam/Polymer Mix ${ }^{\mathrm{a}}$ \\
\hline 8 to 19 liters (2 - 5 gallons) Acrylafoam ${ }^{\circledR \mathrm{b}}$ \\
and \\
4 to 11 liters ( $1-3$ gallons) Acrylavis ${ }^{\circledR \mathrm{b}}$ \\
per \\
7,949 liters (50 barrels) water \\
\hline \hline
\end{tabular}

a During air-foam drilling below approximately 12.5 meters (41 feet), various proportions of polymer were added to suit conditions.

b $\quad$ Acrylafoam ${ }^{\circledR}$ foaming agent and Acrylavis ${ }^{\circledR}$ polymer additive are products of Enterprise Drilling Fluids, Inc.

NOTES:

1. All water used to mix drilling fluids for Well ER-EC-7 came from the Coffer Well.

2. A concentrated solution of lithium bromide was added to all introduced fluids to make up a final concentration of 11 to 105 milligrams per liter.

Table A-3-2

Well ER-EC-7 Cement Composition

\begin{tabular}{|c|c|c|c|}
\hline Cement Composition & $\begin{array}{c}\text { 20-inch Conductor } \\
\text { Casing }\end{array}$ & $\begin{array}{c}\text { 13d -inch Surface } \\
\text { Casing }\end{array}$ & Completion \\
\hline $\begin{array}{c}\text { Type II plus } \\
25 \text { percent sand } \\
\text { ("75/25") }\end{array}$ & $\begin{array}{l}4.3^{c} \text { to } 12.5 \mathrm{~m}^{\mathrm{a}} \\
\left(14^{\mathrm{c}} \text { to } 41.0 \mathrm{ft}^{\mathrm{b}}\right)\end{array}$ & Not used & Not used \\
\hline Type II neat & $\begin{array}{l}0 \text { to } 4.3^{c} \mathrm{~m} \\
\left(0 \text { to } 14^{c} \mathrm{ft}\right)\end{array}$ & $\begin{array}{c}\text { Above cement baskets } \\
0 \text { to } 16.5 \mathrm{~m} \\
(0 \text { to } 54 \mathrm{ft}) \\
207.6^{\mathrm{c}} \text { to } 266.7 \mathrm{~m} \\
\left(681^{\mathrm{c}} \text { to } 875 \mathrm{ft}\right)\end{array}$ & $\begin{array}{c}172.8 \text { to } 272.8 \mathrm{~m} \\
(567 \text { to } 895 \mathrm{ft}) \\
312.1 \text { to } 351.4 \mathrm{~m} \\
(1,024 \text { to } 1,153 \mathrm{ft})\end{array}$ \\
\hline
\end{tabular}
a meter(s)
b foot (feet)
c estimated 
This page intentionally left blank.

A-3-2 


\section{Appendix B \\ Well ER-EC-7 Fluid Management Data}




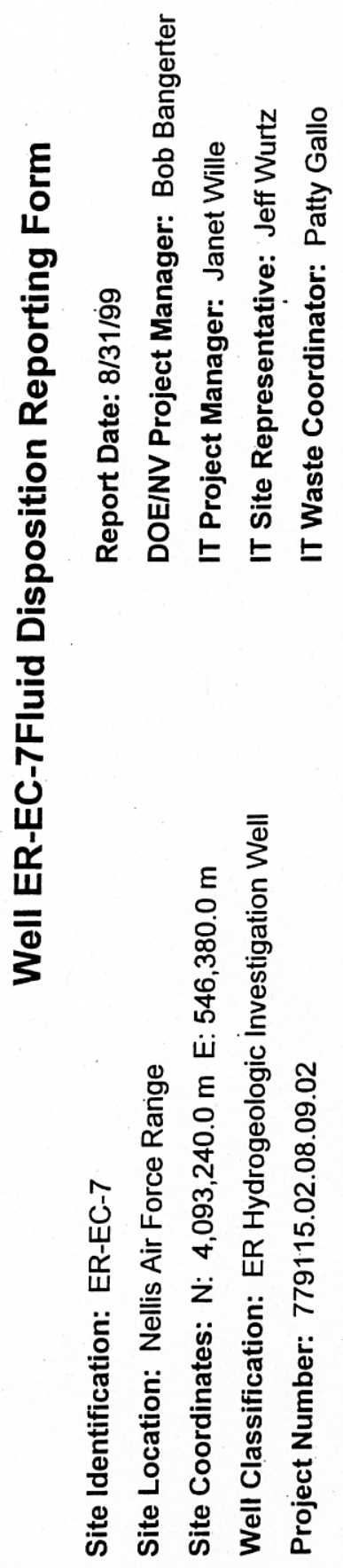

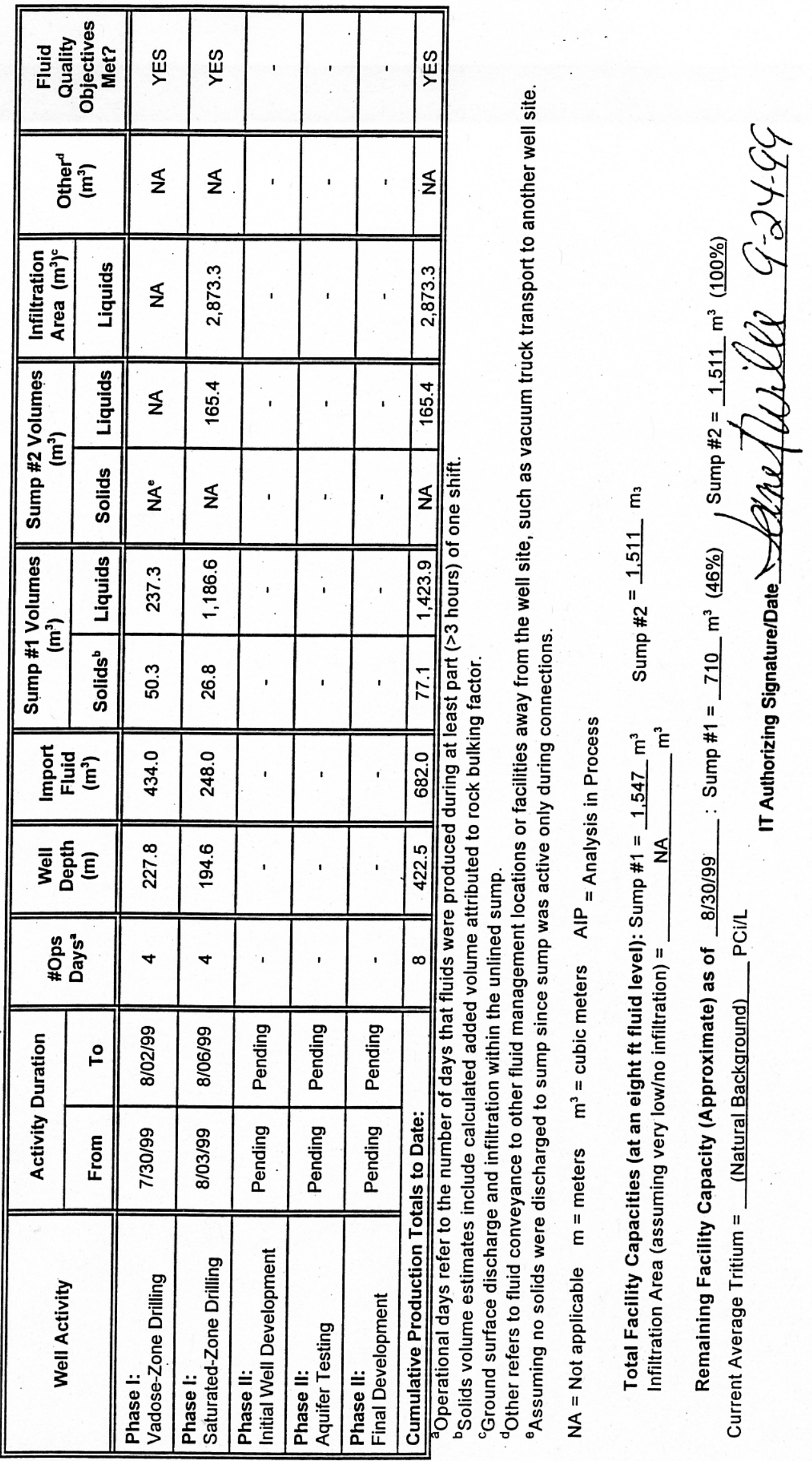


Preliminary Analytical Results for Fluid Management Samples at Well ER-EC-7

\begin{tabular}{|c|c|c|c|c|c|c|c|c|c|c|c|c|c|c|}
\hline \multirow{2}{*}{$\begin{array}{l}\text { Sample } \\
\text { Number }\end{array}$} & \multirow{2}{*}{$\begin{array}{c}\text { Date \& } \\
\text { Time } \\
\text { Collected }\end{array}$} & \multirow{2}{*}{ Comment } & & \multicolumn{8}{|c|}{ Resource Conservation Recovery Act (RCRA) Metals (milligrams per liter) } & \multirow{2}{*}{$\begin{array}{l}\text { Gross } \\
\text { Alpha } \\
\left(^{(p C i / L)^{a}}\right.\end{array}$} & \multirow{2}{*}{$\begin{array}{r}\text { Gross } \\
\text { Beta } \\
\text { (pCi/L) }\end{array}$} & \multirow{2}{*}{$\begin{array}{l}\text { Tritium } \\
(\mathrm{pCi} / \mathrm{L})\end{array}$} \\
\hline & & & & Arsenic & Barium & Cadmium & $\begin{array}{l}\text { Chromiu } \\
\mathrm{m}\end{array}$ & Lead & Selenium & Silver & Mercury & & & \\
\hline \multirow[b]{2}{*}{ EC-7-08039-1 } & \multirow[b]{2}{*}{$\begin{array}{c}\text { 08/03/1999 } \\
09: 20\end{array}$} & \multirow{2}{*}{$\begin{array}{l}\text { Sample taken } \\
\text { from unlined } \\
\text { Sump \#1 }\end{array}$} & Total & 0.029 & 0.38 & $\mathrm{ND}^{\mathrm{b}}$ & 0.026 & 0.077 & 0.0073 & ND & 0.0019 & & & \\
\hline & & & Dissolved & ND & ND & ND & ND & 0.0035 & ND & ND & ND & $\begin{array}{c}51 \\
E^{c}=7.1\end{array}$ & $\begin{array}{c}40.5 \\
E=4.8\end{array}$ & $\begin{array}{c}-110(U)^{d} \\
E=170\end{array}$ \\
\hline \multirow{2}{*}{ EC-7-08069-1 } & \multirow{2}{*}{$\begin{array}{c}08 / 06 / 1999 \\
12: 14\end{array}$} & \multirow{2}{*}{$\begin{array}{l}\text { Sample taken } \\
\text { from unlined } \\
\text { Sump \#1 }\end{array}$} & Total & $\begin{array}{l}0.0074 \\
(B)^{e}\end{array}$ & $\begin{array}{c}0.0786 \\
\text { (B) }\end{array}$ & $\begin{array}{c}0.0002 \\
\text { (U) }\end{array}$ & $\begin{array}{l}0.0032 \\
\text { (B) }\end{array}$ & $\begin{array}{l}0.0027 \\
\text { (B) }\end{array}$ & $\begin{array}{l}0.0024 \\
\text { (B) }\end{array}$ & $\begin{array}{l}0.00066 \\
\text { (B) }\end{array}$ & $\begin{array}{c}0.00002 \\
(U)\end{array}$ & & & \\
\hline & & & Dissolved & $\begin{array}{c}0.0042 \\
\text { (B) }\end{array}$ & $\begin{array}{c}0.0033 \\
\text { (B) }\end{array}$ & $\begin{array}{c}0.0002 \\
\text { (U) }\end{array}$ & $\begin{array}{l}0.00091 \\
\text { (B) }\end{array}$ & $\begin{array}{l}0.0009 \\
\text { (U) }\end{array}$ & $\begin{array}{c}0.0022 \\
\text { (U) }\end{array}$ & $\begin{array}{l}0.0005 \\
\text { (U) }\end{array}$ & $\begin{array}{c}0.00002 \\
(U)\end{array}$ & $\begin{array}{l}6.90 \\
E=30\end{array}$ & $\begin{array}{l}2.06 \\
E=70 \\
(U)\end{array}$ & $\begin{array}{c}-234 \\
E=180 \\
(U)\end{array}$ \\
\hline \multirow[b]{2}{*}{ EC-7-08069-2 } & \multirow{2}{*}{$\begin{array}{c}08 / 06 / 1999 \\
12: 14\end{array}$} & \multirow{2}{*}{$\begin{array}{l}\text { Duplicate } \\
\text { sample taken } \\
\text { from unlined } \\
\text { Sump \#1 }\end{array}$} & Total & $\begin{array}{l}0.005 \\
\text { (B) }\end{array}$ & $\begin{array}{c}0.0475 \\
\text { (B) }\end{array}$ & $\begin{array}{c}0.0002 \\
\text { (U) }\end{array}$ & $\begin{array}{c}0.0015 \\
\text { (B) }\end{array}$ & $\begin{array}{l}0.0009 \\
(U)\end{array}$ & $\begin{array}{l}0.0022 \\
\text { (U) }\end{array}$ & $\begin{array}{l}0.0005 \\
\text { (U) }\end{array}$ & $\begin{array}{c}0.00002 \\
(U)\end{array}$ & & & \\
\hline & & & Dissolved & $\begin{array}{l}0.004 \\
\text { (B) }\end{array}$ & $\begin{array}{c}0.0029 \\
\text { (B) }\end{array}$ & $\begin{array}{c}0.0002 \\
\text { (U) }\end{array}$ & $\begin{array}{l}0.00087 \\
\text { (B) }\end{array}$ & $\begin{array}{l}0.0009 \\
\text { (U) }\end{array}$ & $\begin{array}{l}0.0027 \\
\text { (B) }\end{array}$ & $\begin{array}{l}0.0005 \\
\text { (U) }\end{array}$ & $\begin{array}{c}0.00002 \\
(U)\end{array}$ & $\begin{array}{c}6.85 \\
E=30\end{array}$ & $\begin{array}{l}2.89 \\
E=48\end{array}$ & $\begin{array}{c}-17.5 \\
E=2,500 \\
(U)\end{array}$ \\
\hline \multirow[b]{2}{*}{ EC-7-08069-3 } & \multirow{2}{*}{$\begin{array}{c}08 / 06 / 1999 \\
13: 55\end{array}$} & \multirow{2}{*}{$\begin{array}{l}\text { Sample taken } \\
\text { from unlined } \\
\text { Sump \#2 }\end{array}$} & Total & $\begin{array}{c}0.0052 \\
\text { (B) }\end{array}$ & $\begin{array}{l}0.0363 \\
\text { (B) }\end{array}$ & $\begin{array}{c}0.0002 \\
\text { (U) }\end{array}$ & $\begin{array}{c}0.0014 \\
\text { (B) }\end{array}$ & $\begin{array}{c}0.0009 \\
\text { (U) }\end{array}$ & $\begin{array}{c}0.0022 \\
\text { (U) }\end{array}$ & $\begin{array}{c}0.0005 \\
\text { (U) }\end{array}$ & $\begin{array}{l}0.00003 \\
\text { (B) }\end{array}$ & & & \\
\hline & & & Dissolved & $\begin{array}{l}0.0044 \\
\text { (B) }\end{array}$ & $\begin{array}{c}0.0025 \\
\text { (B) }\end{array}$ & $\begin{array}{c}0.0002 \\
\text { (U) }\end{array}$ & $\begin{array}{l}0.0004 \\
\text { (U) }\end{array}$ & $\begin{array}{l}0.0009 \\
\text { (U) }\end{array}$ & $\begin{array}{l}0.0044 \\
\text { (B) }\end{array}$ & $\begin{array}{l}0.0005 \\
\text { (U) }\end{array}$ & $\begin{array}{c}0.00002 \\
(U)\end{array}$ & $\begin{array}{c}13.2 \\
E=18\end{array}$ & $\begin{array}{l}1.95 \\
E=68 \\
(U)\end{array}$ & $\begin{array}{c}-23.4 \\
E=1,900\end{array}$ \\
\hline \multicolumn{4}{|c|}{ Contract-Required Detection Limit } & 0.01 & 0.1 & 0.005 & 0.01 & 0.003 & 0.005 & 0.01 & 0.0002 & $N / A^{f}$ & N/A & N/A \\
\hline \multicolumn{4}{|c|}{ Nevada Drinking Water Standard (NDWS) } & 0.05 & 2.0 & 0.005 & 0.1 & 0.015 & 0.05 & 0.1 & 0.002 & 15 & 50 & 20,000 \\
\hline \multicolumn{4}{|c|}{5 Times NDWS } & 0.25 & 10 & 0.025 & 0.5 & 0.075 & 0.25 & 0.5 & 0.01 & 75 & 250 & 100,000 \\
\hline
\end{tabular}

a $\quad \mathrm{pC} / \mathrm{L}=$ Picocuries per liter

Data provided by IT Corp (IT, 1999).

b ND $=$ Not detected

c $\mathrm{E}=$ Error

d $\quad U=$ Result less than the Instrument Detection Limit or the Minimum Detectable Concentration.

e $\quad B=$ Result less than the Contract Required Detection Limit but greater than the Instrument Detection Limit

f $\quad N / A=$ Not applicable 


\section{Appendix C \\ Detailed Lithologic Log for Well ER-EC-7}


Detailed Lithologic Log for ER-EC-7

Logged by Heather Noto and Lance Prothro, Bechtel Nevada

(Log incorporates information from petrographic, mineralogic, and chemical analyses

provided by R. G. Warren, Los Alamos National Laboratory)

\begin{tabular}{|c|c|c|c|c|c|}
\hline $\begin{array}{c}\text { Depth } \\
\text { Interval } \\
\text { meters (feet) }\end{array}$ & $\begin{array}{c}\text { Thickness } \\
\text { meters } \\
\text { (feet) }\end{array}$ & $\begin{array}{l}\text { Sample } \\
\text { Type }^{a}\end{array}$ & $\begin{array}{l}\text { Laboratory } \\
\text { Analyses }\end{array}$ & Lithologic Description ${ }^{c}$ & $\begin{array}{l}\text { Stratigraphic } \\
\text { Unit }\end{array}$ \\
\hline $\begin{array}{l}0-12.5 \\
(0-41)\end{array}$ & $\begin{array}{l}12.5 \\
(41)\end{array}$ & None & None & $\begin{array}{l}\text { Alluvium: Interval based on surface geology and the depth that auger rig } \\
\text { failed to penetrate the rocks below. }\end{array}$ & $\begin{array}{c}\text { Young } \\
\text { alluvium (Qay) }\end{array}$ \\
\hline $\begin{array}{r}12.5-49.4 \\
(41-162)\end{array}$ & $\begin{array}{l}36.9 \\
(121)\end{array}$ & DA & $\begin{array}{c}\mathrm{PTS}, \mathrm{XRD}, \\
\text { XRF, } \\
\mathrm{Fe}^{2+} / \mathrm{Fe}^{3+}\end{array}$ & $\begin{array}{l}\text { Pumiceous Lava: Grayish yellow (5Y 8/4), dusky yellow (5Y 6/4), } \\
\text { yellowish gray (5Y } 8 / 1 \text { ), and dark yellowish brown (10YR 4/2); devitrified with } \\
\text { vapor-phase mineralization, lesser silicic with conspicuous secondary } \\
\text { chalcedony present as loose fragments in cuttings samples; rare to minor } \\
\text { felsic phenocrysts of feldspar; common biotite and conspicuous } \\
\text { pseudomorphs after sphene. }\end{array}$ & \multirow{5}{*}{$\begin{array}{l}\text { rhyolite of } \\
\text { Beatty Wash } \\
\text { (Tfbw) }\end{array}$} \\
\hline $\begin{array}{l}49.4-62.2 \\
(162-204)\end{array}$ & $\begin{array}{l}12.8 \\
(42)\end{array}$ & DA & None & $\begin{array}{l}\text { Lava: Medium gray (N5), dusky yellow (5Y 6/4), dark yellowish brown } \\
\text { (10YR 4/2), light olive gray (5Y 5/2), and yellowish gray (5Y } 8 / 1) \text {; partially } \\
\text { zeolitic, vitric, and silicic; strongly perlitic where vitric; minor felsic } \\
\text { phenocrysts of feldspar; common biotite and conspicuous sphene. }\end{array}$ & \\
\hline $\begin{array}{l}62.2-98.5 \\
(204-323)\end{array}$ & $\begin{array}{l}36.3 \\
(119)\end{array}$ & DA & None & $\begin{array}{l}\text { Lava: Medium gray (N5), greenish gray (5GY 6/1), light olive gray (5Y 6/1), } \\
\text { brownish black (5YR 2/1), dusky yellowish brown (10YR 2/2), and moderate } \\
\text { brown (5YR 4/4); mostly vitric, much lesser silicic, zeolitic at base; strongly } \\
\text { perlitic; rare to minor felsic phenocrysts of feldspar; common biotite, trace } \\
\text { hornblende, and conspicuous sphene. }\end{array}$ & \\
\hline $\begin{array}{l}98.5-131.4 \\
(323-431)\end{array}$ & $\begin{array}{l}32.9 \\
(108)\end{array}$ & DA & None & $\begin{array}{l}\text { Lava: Medium light gray (N6), medium gray (N5), pale reddish brown } \\
\text { (10R 5/4), and pale red (5R 6/2); quartzo-feldspathic with significant } \\
\text { silicification; spherulitic; strongly flowbanded; minor felsic phenocrysts of } \\
\text { partially altered feldspar; common biotite and partially altered biotite, and } \\
\text { conspicuous pseudomorphs after sphene. }\end{array}$ & \\
\hline $\begin{array}{c}131.4-268.2 \\
(431-880)\end{array}$ & $\begin{array}{l}136.9 \\
(449)\end{array}$ & DA & None & $\begin{array}{l}\text { Lava: Medium light gray (N6) above approximately } 182.9 \mathrm{~m} \text { (600 ft), } \\
\text { becoming mottled with light brown (5YR 6/4) below; quartzo-feldspathic; rare } \\
\text { to minor felsic phenocrysts of feldspar, some partially altered; common } \\
\text { biotite, many altered to bronze color, and conspicuous sphene and } \\
\text { pseudomorphs after sphene. }\end{array}$ & \\
\hline
\end{tabular}




\begin{tabular}{|c|c|c|c|c|c|}
\hline $\begin{array}{c}\text { Depth } \\
\text { Interval } \\
\text { meters (feet) }\end{array}$ & $\begin{array}{c}\text { Thickness } \\
\text { meters } \\
\text { (feet) }\end{array}$ & $\begin{array}{l}\text { Sample } \\
\text { Type a }^{\text {a }}\end{array}$ & $\begin{array}{l}\text { Laboratory } \\
\text { Analyses }\end{array}$ & Lithologic Description ${ }^{c}$ & $\begin{array}{c}\text { Stratigraphic } \\
\text { Unit }\end{array}$ \\
\hline $\begin{array}{c}268.2-289.6 \\
(880-950)\end{array}$ & $\begin{array}{l}21.3 \\
(70)\end{array}$ & DA & None & $\begin{array}{l}\text { Lava: Mottled medium gray (N5) and light brown (5YR 6/4); quartzo- } \\
\text { feldspathic, with significant silicification; flowbanded; rare to minor felsic } \\
\text { phenocrysts of feldspar, some partially altered; minor to common biotite, } \\
\text { some altered to bronze color; sphene is present. }\end{array}$ & \multirow{4}{*}{ Tfbw } \\
\hline $\begin{array}{c}289.6-302.7 \\
(950-993)\end{array}$ & $\begin{array}{l}13.1 \\
(43)\end{array}$ & DA & None & $\begin{array}{l}\text { Flow Breccia: Grayish red (10R 5/2) and moderate brown (5YR 4/4); } \\
\text { quartzo-feldspathic with significant silicification; spherulitic; minor felsic } \\
\text { phenocrysts of partially altered feldspar and pseudomorphs after feldspar; } \\
\text { common biotite and conspicuous sphene; numerous hairline, silica-filled } \\
\text { fractures. }\end{array}$ & \\
\hline $\begin{array}{l}302.7-305.7 \\
(993-1,003)\end{array}$ & $\begin{array}{c}3.0 \\
(10)\end{array}$ & DA & $\begin{array}{c}\text { PTS, XRD, } \\
\text { XRF, } \\
\mathrm{Fe}^{2+} / \mathrm{Fe}^{3+}\end{array}$ & $\begin{array}{l}\text { Vitrophyric Lava: Dusky brown (5YR } 2 / 2) \text { to brownish black (5YR } 2 / 1) \text {; } \\
\text { vitric, zeolitic at top; very weakly perlitic; minor to common felsic } \\
\text { phenocrysts of feldspar; minor biotite and conspicuous sphene, hornblende } \\
\text { observed in thin section. }\end{array}$ & \\
\hline $\begin{array}{c}305.7-314.2 \\
(1,003-1,031)\end{array}$ & $\begin{array}{l}8.5 \\
(28)\end{array}$ & DA & $\begin{array}{c}\text { PTS, XRD, } \\
\text { XRF, } \\
\mathrm{Fe}^{2+} / \mathrm{Fe}^{3+}\end{array}$ & $\begin{array}{l}\text { Flow Breccia: Dusky yellow (5Y 6/4), grayish red (10R 4/2), and pale } \\
\text { yellowish brown (10YR } 6 / 2) \text {; devitrified (matrix) and quartzo-feldspathic } \\
\text { (clasts) with significant silicification; spherulitic; minor felsic phenocrysts of } \\
\text { partially altered feldspar and pseudomorphs after feldspar; minor to common } \\
\text { unaltered biotite; altered sphene is present. }\end{array}$ & \\
\hline $\begin{array}{c}314.2-352.0 \\
(1,031-1,155)\end{array}$ & $\begin{array}{l}37.8 \\
(124)\end{array}$ & DA & $\begin{array}{c}\text { PTS, MP, } \\
\text { XRD, XRF, } \\
\mathrm{Fe}^{2+} / \mathrm{Fe}^{3+}\end{array}$ & $\begin{array}{l}\text { Bedded Tuff: Pale reddish brown (10R } 5 / 4) \text {, grayish orange pink ( } 5 \text { YR } 7 / 2) \text {, } \\
\text { pinkish gray (5YR } 8 / 1) \text {, and yellowish gray ( } 5 \text { Y } 8 / 1) \text {; quartzo-feldspathic; } \\
\text { common moderate-greenish-yellow (10Y } 7 / 4) \text { and pale-greenish-yellow } \\
\text { (10Y } 8 / 2 \text { ) pumice; rare felsic phenocrysts of feldspar and quartz, common } \\
\text { felsic phenocrysts of plagioclase, sanidine, and much less quartz observed } \\
\text { in thin section; rare biotite, pseudomorphs of sphene and clinopyroxene } \\
\text { observed in thin section; minor to common lithic fragments observed in thin } \\
\text { section. }\end{array}$ & $\begin{array}{l}\text { rhyolite of } \\
\text { Chukar } \\
\text { Canyon } \\
\text { (Tfbr) }\end{array}$ \\
\hline
\end{tabular}




\begin{tabular}{|c|c|c|c|c|c|}
\hline $\begin{array}{c}\text { Depth } \\
\text { Interval } \\
\text { meters (feet) } \\
\end{array}$ & $\begin{array}{c}\text { Thickness } \\
\text { meters } \\
\text { (feet) }\end{array}$ & $\begin{array}{l}\text { Sample } \\
\text { Type }^{\text {a }}\end{array}$ & $\begin{array}{l}\text { Laboratory } \\
\text { Analyses }\end{array}$ & Lithologic Description $^{c}$ & $\begin{array}{c}\text { Stratigraphic } \\
\text { Unit }\end{array}$ \\
\hline $\begin{array}{c}352.0-369.1 \\
(1,155-1,211)\end{array}$ & $\begin{array}{l}17.1 \\
(56)\end{array}$ & DA & $\begin{array}{c}\text { PTS, XRD, } \\
\text { XRF, } \\
\mathrm{Fe}^{2+} / \mathrm{Fe}^{3+}\end{array}$ & $\begin{array}{l}\text { Lava: Mottled very-pale-orange (10YR 8/2), yellowish-gray ( } 5 Y \text { Y/2), and } \\
\text { pale-reddish-brown (10R } 5 / 4) \text {; quartzo-feldspathic; remnant perlitic texture; } \\
\text { common felsic phenocrysts of partially altered feldspar and pseudomorphs } \\
\text { after feldspar, and lesser quartz; common partially altered biotite, mafic } \\
\text { pseudomorphs that probably represent clinopyroxene were observed in thin } \\
\text { section. }\end{array}$ & Tfbr \\
\hline $\begin{array}{c}369.1-396.2 \\
(1,211-1,300)\end{array}$ & $\begin{array}{l}27.1 \\
(89)\end{array}$ & $\mathrm{DA}$ & $\begin{array}{c}\text { PTS, XRD, } \\
\text { XRF, } \\
\mathrm{Fe}^{2+} / \mathrm{Fe}^{3+}\end{array}$ & $\begin{array}{l}\text { Lava: Moderate reddish brown (10R 4/6); laboratory analyses indicate } \\
\text { diverse primary and secondary alteration including devitrification, quartzo- } \\
\text { feldspathic, zeolitic, and silicic; spherulitic and flow banded; minor to } \\
\text { common felsic phenocrysts of unaltered to partially altered feldspar; } \\
\text { common mostly unaltered biotite, sphene observed in thin section. }\end{array}$ & $\begin{array}{l}\text { Beatty Wash } \\
\text { Formation } \\
\text { (Tfb) }\end{array}$ \\
\hline $\begin{array}{c}396.2-422.5 \\
(1,300-1,386) \\
\text { TD }\end{array}$ & $\begin{array}{l}26.2 \\
(86)\end{array}$ & DA & $\begin{array}{c}\text { PTS, MP, } \\
\text { XRD, XRF, } \\
\mathrm{Fe}^{2+} / \mathrm{Fe}^{3+}\end{array}$ & $\begin{array}{l}\text { Lava: Moderate reddish brown (10R 4/6); laboratory analyses indicate } \\
\text { diverse primary and secondary alteration including devitrification, quartzo- } \\
\text { feldspathic, zeolitic, and silicic; spherulitic and flow banded; abundant felsic } \\
\text { phenocrysts of mostly partially altered feldspar and pseudomorphs after } \\
\text { feldspar; common partially altered biotite, clinopyroxene observed in thin } \\
\text { section. }\end{array}$ & $\begin{array}{l}\text { tuff of } \\
\text { Leadfield } \\
\text { Road } \\
\text { (Tfl) }\end{array}$ \\
\hline
\end{tabular}

a $\quad \mathbf{D A}=$ drill cuttings that represent lithologic character of interval.

b $\quad \mathbf{P T S}=$ polished thin section; $\mathbf{M P}=$ electron microprobe; $\mathbf{X R D}=\mathbf{X}$-ray diffraction; $\mathbf{X R F}=\mathbf{X}$-ray fluorescence;

$\mathrm{Fe}^{2+} / \mathrm{Fe}^{3+}=$ wet chemical analysis for iron. See Table 3-2 of this report for sample depths.

c Descriptions are based on visual examination of lithologic samples using a 10x-to 40x-zoom binocular microscope and geophysical logs. Colors describe wet sample color.

Abundances for felsic phenocrysts, pumice fragments, and lithic fragments: trace $=$ only one or two individuals observed; rare $=\leq 1 \%$; minor $=5 \%$; common $=10 \% ;$ abundant $=15 \%$; very abundant $=\geq 20 \%$

Abundances for mafic minerals: trace $=$ only one or two individuals observed; rare $=\leq 0.05 \% ;$ minor $=0.2 \% ;$ common $=0.5 \%$;

abundant $=1 \%$; very abundant $=\geq 2 \%$ 
This page intentionally left blank.

C-4 
Appendix D

Geophysical Logs Run in Well ER-EC-7 
Appendix D contains unprocessed data presentations of selected geophysical logs run in Well ER-EC-7. Table D-1 summarizes the logs presented. See Table 3-2 for more information.

Table D-1

Well ER-EC-7 Geophysical Logs Presented

\begin{tabular}{|c|c|c|c|c|}
\hline Log Type & $\begin{array}{l}\text { Run } \\
\text { Number }\end{array}$ & Date & meters & feet \\
\hline Epithermal Neutron & ENP-1 & 08/08/1999 & $0-398.7$ & $0-1,308$ \\
\hline Density & CDL-1 & 08/08/1999 & $0-398.7$ & $0-1,308$ \\
\hline $\begin{array}{l}\text { Dual Laterolog } \\
\text { (resistivity) }\end{array}$ & DLL-1 & 08/08/1999 & $265.5-394.7$ & $871-1,295$ \\
\hline Spontaneous Potential & SP-1 & 08/08/1999 & $265.5-394.7$ & $871-1,295$ \\
\hline Gamma Ray & GR-3 & 08/08/1999 & $265.5-394.7$ & $871-1,295$ \\
\hline $\begin{array}{c}\text { Digital Array Sonic } \\
\text { (delta T, sonic porosity) }\end{array}$ & AC-1 & 08/08/1999 & $258.5-393.8$ & $848-1,292$ \\
\hline $\begin{array}{c}\text { Spectral Gamma Ray } \\
\text { (potassium, thorium, uranium) }\end{array}$ & SGR-1 & 08/08/1999 & $0-386.5$ & $0-1,268$ \\
\hline Thermal Flow & 1 & 08/07/1999 & $257.6-397.8$ & $845-1,305$ \\
\hline $\begin{array}{c}\text { Chemistry } \\
\text { (temperature, } \mathrm{pH} \text {, electrical conductivity) }\end{array}$ & 1 & 08/07/1999 & $228.0-400.5$ & $748-1,314$ \\
\hline
\end{tabular}




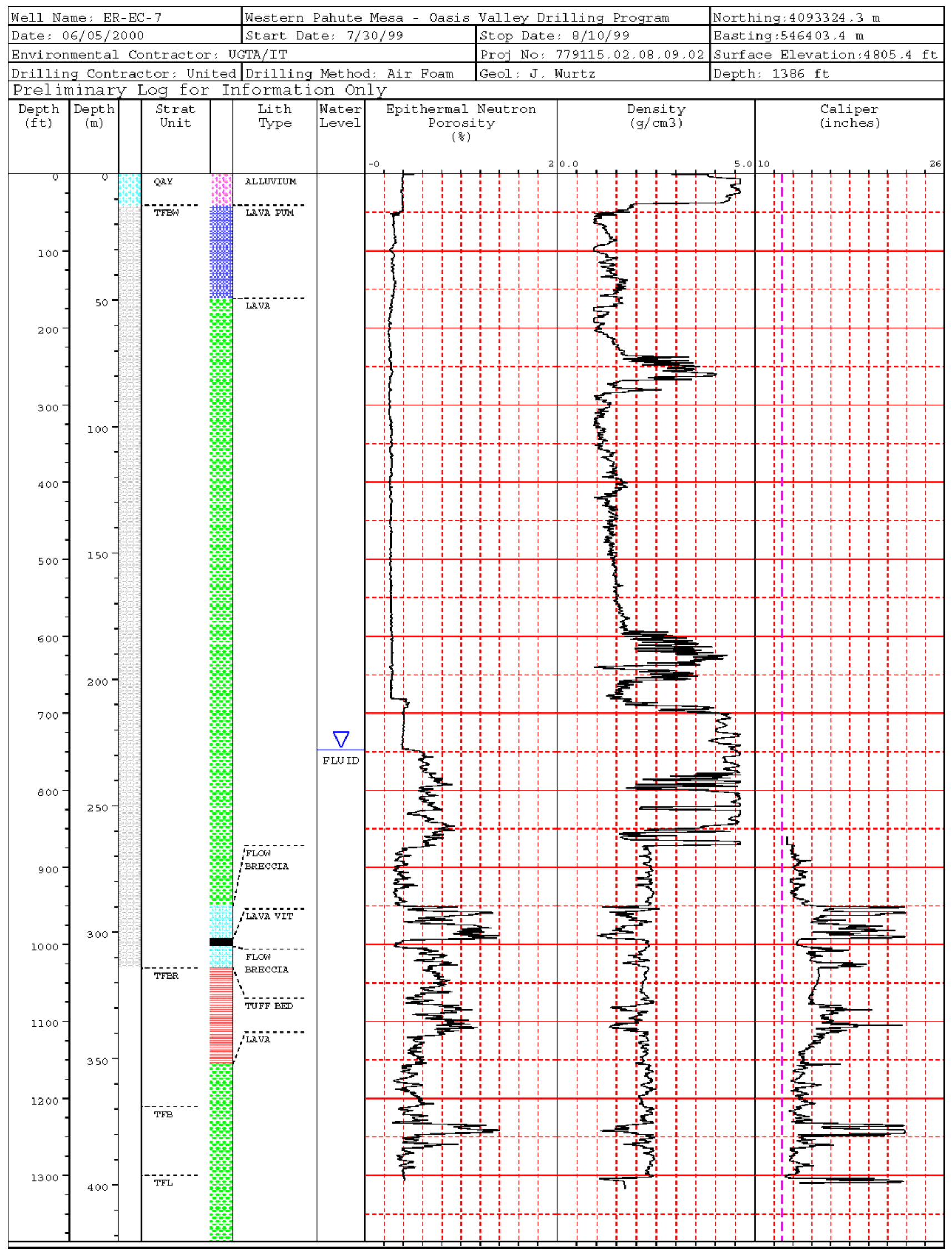




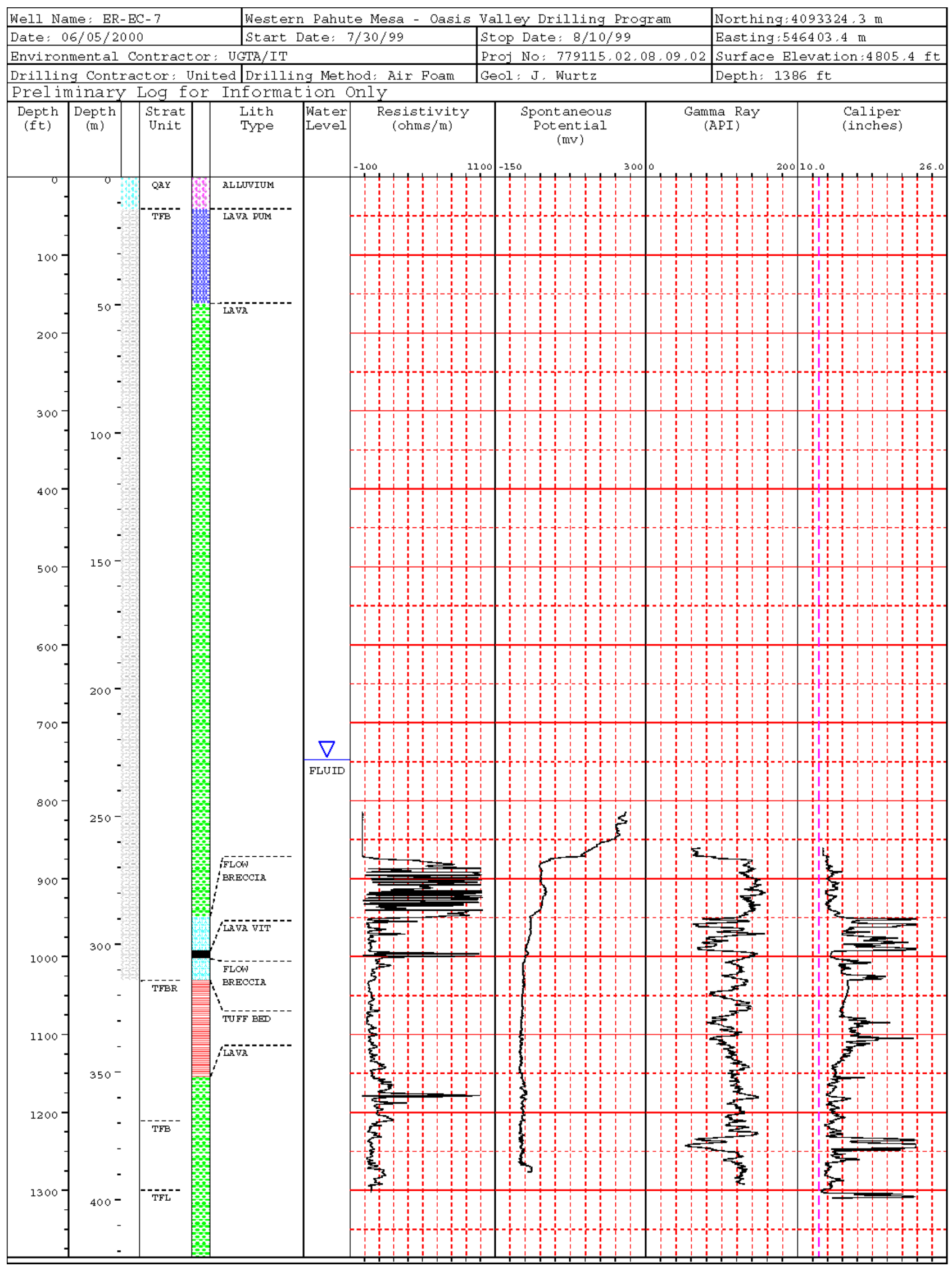




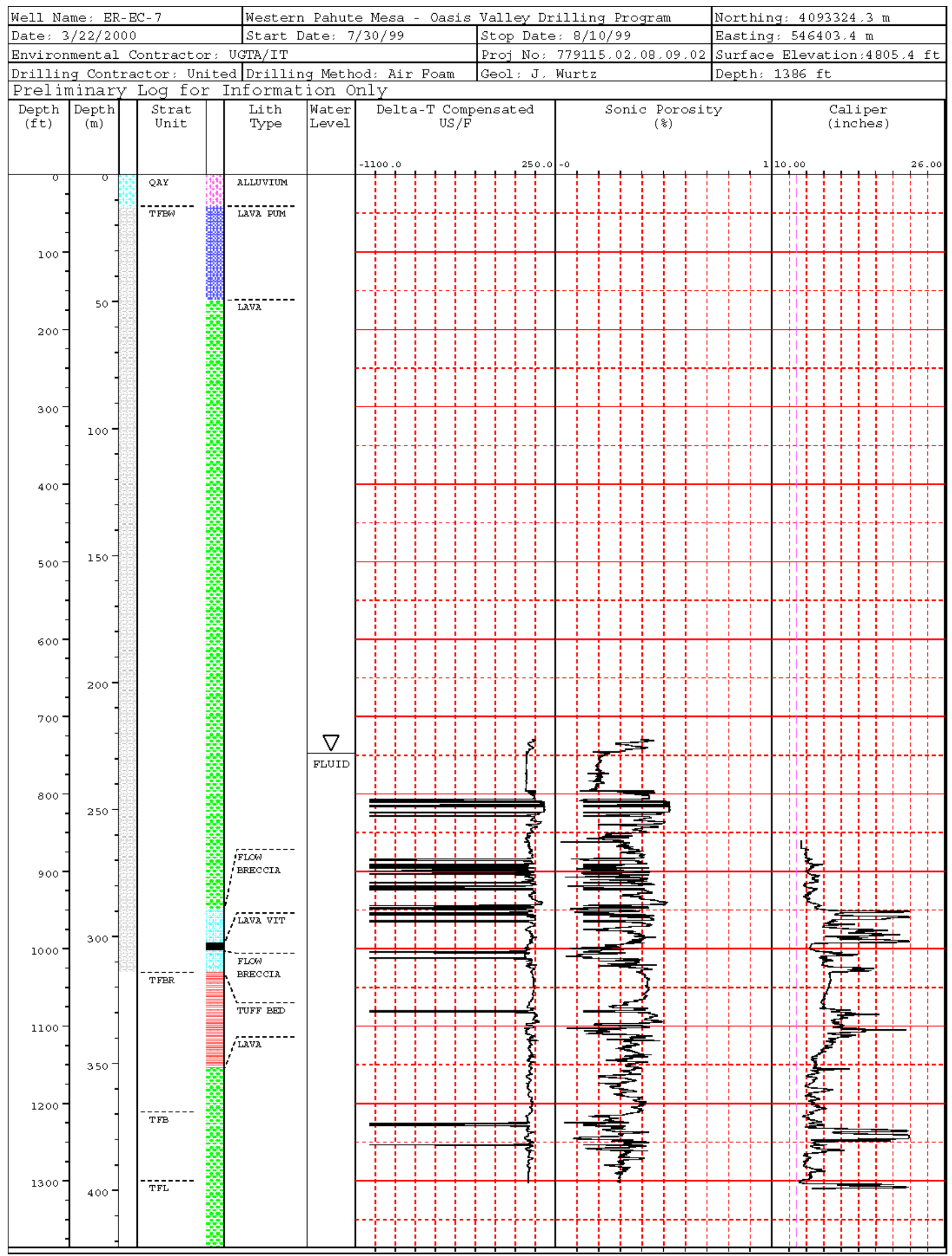




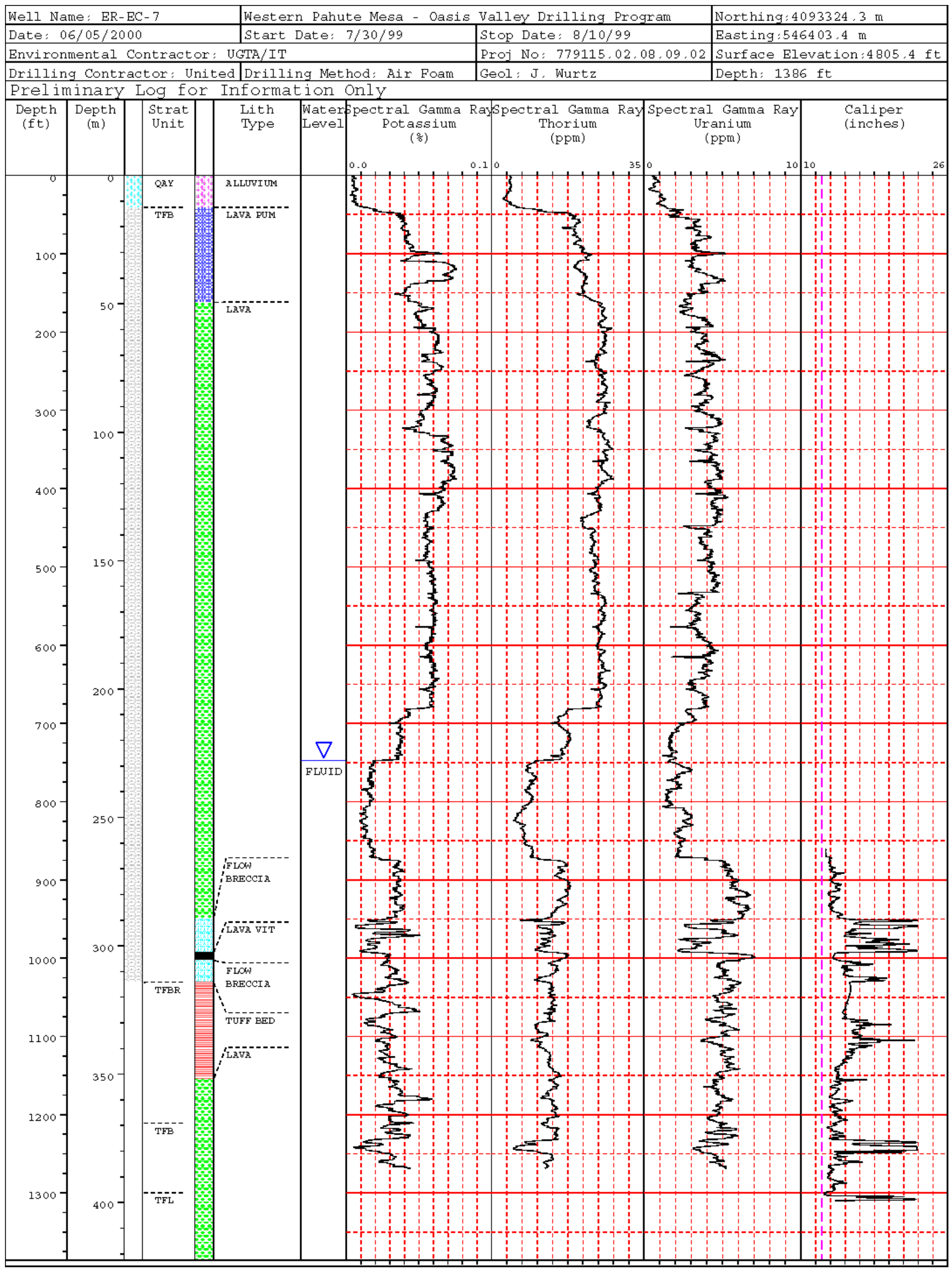




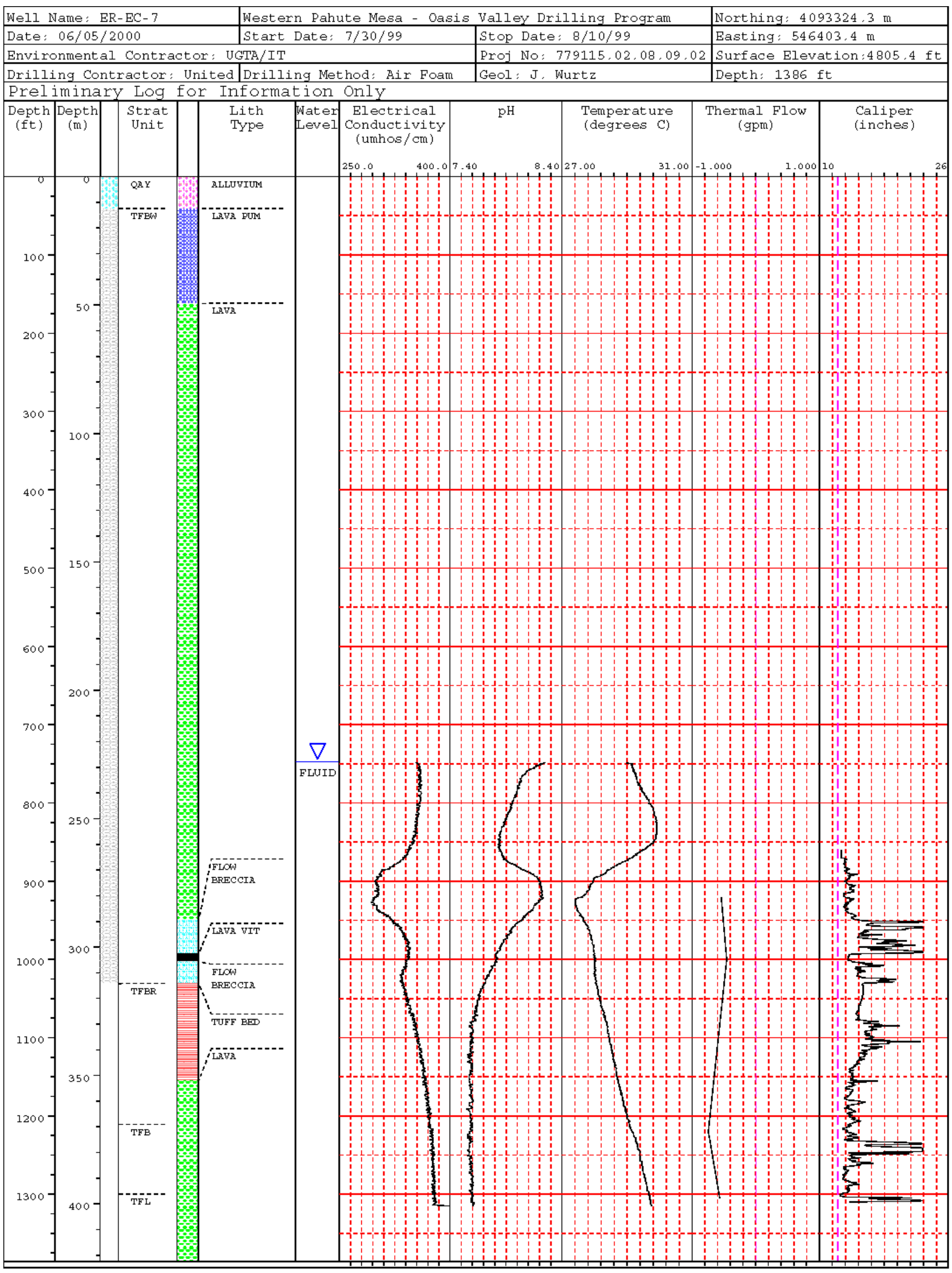




\section{Distribution List}

\section{$\underline{\text { Copies }}$}

R. M. Bangerter

U.S. Department of Energy

National Nuclear Security Administration

Nevada Site Office

Environmental Restoration Division

P.O. Box 98518, M/S 505

Las Vegas, NV 89193-8518

U.S. Department of Energy

National Nuclear Security Administration

Nevada Site Office

Technical Library

P.O. Box 98518, M/S 505

Las Vegas, NV 89193-8518

U.S. Department of Energy

National Nuclear Security Administration

Nevada Site Office

Public Reading Facility

P.O. Box 98518, M/S 505

Las Vegas, NV 89193-8518

U.S. Department of Energy

1 (electronic)

Office of Scientific and Technical Information

Post Office Box 62

Oak Ridge, Tennessee 37831-0062

K. A. Hoar, Director

U.S. Department of Energy

National Nuclear Security Administration

Nevada Site Office

Environment, Safety and Health Division

P.O. Box 98518, M/S 505

Las Vegas, NV 89193-8518

P. K. Ortego

Bechtel Nevada

P.O. Box 98521, MS NLV082

Las Vegas, NV 89193-8521 


\section{Distribution List (continued)}

\section{$\underline{\text { Copies }}$}

John McCord

UGTA Project Manager

Stoller-Navarro

7710 West Cheyenne Ave.

Building 3

Las Vegas, NV 89129

Stoller-Navarro Library

Stoller-Navarro

7710 West Cheyenne Ave.

Building 3

Las Vegas, NV 89129

W. L. Hawkins

Los Alamos National Laboratory

P. O. Box 1663

Los Alamos, NM 87545-1663

G. A. Pawloski

Lawrence Livermore National Laboratory

P. O. Box 808

Livermore, CA 94551-0808

T. P. Rose

Lawrence Livermore National Laboratory

P. O. Box 808

Livermore, CA 94551-0808

B. K. Thompson

DOE/USGS Cooperative Program Manager

U.S. Geological Survey

Water Resources Division

6770 South Paradise Road

Las Vegas, NV 89119-3721

C. E. Russell

Desert Research Institute

755 East Flamingo Road

P.O. Box 19040

Las Vegas, NV 89119-7363 